\title{
TÜRK KAMU YÖNETIMI VE HUKUKUNDA KANUN HÜKMÜNDE KARARNAME (1982 ANAYASASI'NIN 91. MADDESININ DEĞERLENDÍRÍLMESİ)
}

\author{
Dr. R. Cengiz DERdimaN*
}

\section{GIRIş}

Aslında her bir yönü ayn bir inceleme konusu olabilecek kadar kapsamlı olan, hukukumuzda ve bazı devletlerin Anayasalarında yer alan Kanun Hükmünde Kararnane (KHK) kurumu, yapılan uygulamalara esas olmak üzere, oncelikle hukukumuzda yer alıs biçimi ile incelenmeli ve değerlendirilmelidir. Aynca hatırlatmaya gerek yoktur ki, bu tür inceleme ve değerlendirmeler, konu ile ilgili çeşitli düşüncelerin ve kanaatlerin ortaya konması ve tartışılması fırsatı da verecektir.

Yukarıdaki sebeplerie; bu çalışmada 1982 Türk Anayasası'nın bilhassa 91 . maddesi esas alınarak, çeşitli yönleriyle Türk Kamu Yönetiminde ve Hukukunda KHK incelenmiştir.

Kısaca belirtmek gerekirse, bu araştırmada, KHK'ye; tanımı, gereklilik nedenleri, düzenleyici işlemler ve yönetim ile ilgisi, unsurları ve özellikleri ve "Yetki kanunu" ile ilişkisi bakımından yer verilmiştir. Bu bilgilerin üzerine, belki de bir sonuç özelliği taşıyacak şekilde, son bölümde KHK'lerin hukuka uygunluğu için gereken önemli hususlar ortaya konulmaya çalışılmıştır.

Buna karşlık;

1- Olağanüstü haller ve sıkıyönetim sırasında, bu olağan dışı yönctimlerin gerekleri için çıkanlacak KHK'lerc (bu incelemede) yer verilmemiştir. Eşdeyişle olağanüstii hal KHK'leri çalışmada aynk tutulmuştur.

*Tokat Emniyet Mưduurlügüu, 4. Sinıf Emniyet Müdürü. 
Değişikliği çalışmanın yapııı̆ı̆ı zamanlara rastlayan (424 sayılı kararla değişik) TBMM lçtüzügüu'nün KHK ile ilgili 37 . ve 90 . maddelerine çok yüzeysel olarak değinilmiştir.

2- Gerek Türk hukukunda ve gerekse diğer devletlerin Anayasalarında KHK'yle ilgili veya benzer sayılabilecek kurumlara ve düzenlemelere, karşılaşırma veya katkı sureti ile konuyu en iyi şekilde ortaya koyabilmek için yerverilmiştir.

3- Sürekli yazılması gerektiği için Kanun Hükmünde Kararname deyimi, (yukanda yapılmış olduğu gibi) "KHK" şeklinde kısaltılmış; Anayasa'mızda kullanılan deyim olması dolayısıyla da bu ifade tercih edilmiştir.

\section{1- KHK'LERE ILISSKIN GENEL BİLGI}

\section{A- KHK'lerin Nitelikleri, Gereklilik Nedenleri ve Tanımları}

KHK kurumu kamu hukumuza ve yönetimimize bugünkü anlamda ilk kez 1961 Anayasası döneminde, bu Anayasa'da 1971 tarihli ve 1488 sayılı kanunla yapılan değişiklik ve eklemelerle girmiştir. 1961 Anayasası döneminde yürütmenin, "kanunlar çerçevesinde" yerine getirilen bir görev olması dolayısıyla, değişen şartlara ve gelişmelere paralel olarak işlemediği ve bu sebeplerle kuvvetlendirilmesi yönündeki görüşlerin etkisiyle ${ }^{1}$, Bakanlar Kurulu'na (yukarıdaki belirtilen şekilde) 1961 Anayasası'nın 64. maddesi ile KHK çıarma yetkisi verilmiştir.

Aslında Anayasa Mahkemesi'nin bu düzenlhemeden önceki kararlarıyla, kanunlarda belirtilen "genel esaslara" göre yürütmeye düzenleme yapabilmesi için geniß̧ bir takdir yetkisi doğmuş ólmakla birlikte, yürütmenin Anayasa Mahkemesi'nin açtoği bu yolu iyi kullanamaması da KHK'nin hukukumuza girmesinde etkili olmuştur ${ }^{2}$.

KHK'nin 1958 tarihli Fransiz (m. 37, 38), 1947 tarihli ttalyan (m. 77) Anayasalarında düzenlediğ $i^{3}$ görülmektedir. 1949 tarihli Bonn Anayasası'nın 80. maddesi de KHK'leri andını bir düzenlemeyi içermektedir. Bu son 80. madde, Almanya'da 1933 tarihli yetki kanunu ile verilen yetkiyi kullanan yürütmenin yaptığı işlem ve eylemlerle yaşanılan acı olaylan tekrar yaşamamak için tüzüklerin yapılmasında dahi uyulması gereken anayasal sınıları ve şartlan kapsar niteliktedir ${ }^{4}$.

${ }^{1}$ Mümtaz Soysal, 100 Soruda Anayasanın Anlamı, Istanbul 1986, s. 336; Kemal Dal, Türk Esas Teşkilat Hukuku, Ankara, 1984, s. 248. Yürütme organının güçlendirilmesi hukukunda bkz. Burhan Kuzu, Anayasa Hukukumuzda Yürütme Organinın Düzenleyici Işlem Yapma Yetkisí ve Güçlendirilmesi Egiliml, Istanbul, 1987, s 150 vd; Turgut Tan, "1982 Anayasası Yönünden Yürütme Görevi ve Yetkisinin Niteliği", Anayasa Yargısı, Ankara, 1984, s. 31 vd.

2 Soysal, a.g.e., 336.

${ }^{3}$ Bkz. Yaşar Gürbüz, Anasayalar, 1stanbul, 1981, s. 77, 114, 115, 144.

${ }^{4}$ Fazıl Sağlam, "KHK Çıkarma Yetkisinin Sınırlanı, Uygulamanın Yaygınlaşmasından Doğabilecek Sorunlar", Anayasa Yargısı, Ankara, 1984, s. 261. Burada yazar, KHK'nin 1961 Anayasasi'na aktarılmasında 1949 tarihli Bonn Anayasasinın 80. maddesinin kaynak olduğunu ve fakat her nasılsa bu maddede KHK'yc yer verilmediği halde tercümenin KHK biçiminde yapıldığını bildirmektedir. Söz konusu 80 . madde için 
Genel olarak, KHK'lerin çeşitli tanımlan yapılabilir. Ömeğin; Fransa'da 1947 tarihli yetki kanunu müzakere edilirken ortaya konulan tanıma göre KHK'ler "Kanun alanına ilişkin nizamnamelerdir" ya da "Yasama konuları üzerine istinad eden karamamelerdir" 5 . Bir başka tanım da KHK'nin farklı ozelliklerini ortaya koyar biçimde "Yetki kanuni vasıtası ile, idari alanlara, başlıca bakanlık ve mahalli makamlara, kaide tasarrufta bulunmak yetkisinhin parlamento tarafından verilmesi" şeklinde yapılmışıır ${ }^{6}$. Bu tanımlar, ülkelerin kendi Anayasal gereklerine ve kurallarına göre değişebilecektir.

Türk hukukunda da bu konuda çeşitli tanımlar yapılmıştır. Örneğin Onar'a göre "...neşredilmiş olan bazı kanunların muayyen sahalarda Bakanlar Kurulu'na verdiği geniş bir tanzim selahiyetine müsteniden Bakanlar Kurulu tarafından ncşredilen kararnemelerdir."7. Bir başka tanıma göre "Yasama organının, bir yetki kanunu ile belli konularda yürütme organına verdiği geniş düzenleme yetkisine dayanılarak Bakanlar Kurulu'nca yapılan genel ve düzenleyici işlemlerdir."8. Teziç KHK'yi "... yasama organının bir kanunla belli konularda yürütmeye verdiği geniş düzenleme yetkisi üzerine Bakanlar Kurulu'nca çıkarılan kararnameler"9 şeklinde tanımlamaktadır. Eroğlu ise tanımla ilgili olarak, "Hükûmet KHK çıkarırken onceden verilen bir yetki kanununa göre kararnameyi çıkarmakta..." demektedir ${ }^{10}$. Tanıma katkı sağlayacağına inanılan bir başka ifadeye göre de "KHK'ler her ne kadar Bakanlar Kurulu tarafindan hazırlanmakta ise de, ... kanun kuvvetindedirler ve bir kanunun yapuğı bütün etkileri yaratırlar."11.

Biz KHK'yi tanımlamadan ơnce tanımı etkileyecek olan diğer baż özelliklerden de bahsetmek isteriz.

Bu ozelliklerin başında, "yasama ycukisinin devredilmezligi" ilkesiyle KHK ilişkisi gelmektedir.

1961 Anayasasının 5., 1982 Anayasası'nın da 7. maddesinde yer alan yasama yetkisinin devredilmezliği prensibi, 1961 Anayasası döneminde, bazı yazarları KHK'yi sıradan bir düzenleyici işlem olarak görmeye yöneltmiştir. Nitekim Duran'a gőre, KHK'nin gerçck yasama yetkisiyle donatılmı̧ güçlü yürütme ortaya çıkarması sözkonusu

bkz. Grundgesetz Für Die Bundesrepublik Deutschland, Bonn, 1986, s. 58; Gürbüz, a.g.e., s. 77.

${ }^{5}$ Burhan Kuzu, Türk Anayasa Hukukunda Kanun Hükmünde Kararnameler, Istanbul, 1985, s. 129.

${ }^{6} \mathrm{Kuzu}$, Türk..., s. 130.

${ }^{7}$ Kuzu, Türk..., s. 131. S. Sami Onar, Idare Hukukunun Umuml Esasları, c. I, Istanbul, 1966, s. 297'den naklen.

${ }^{8} \mathrm{Kuzu}$, Türk..., s. 131, N. Kibar, "Türk Hukukunda Kararname", Idare Hukuku ve Idari Yargi ile Ilgili Incelemeler, III. Ankara, 1980, s. 294'den naklen.

${ }^{9}$ Erdoğan Teziç, "Yasama Yetkisi ve Kanun Hükmünde Kararnameler", Amme Idaresi Dergisi, c. V, s. 1, Ankara, 1972, s. 8.

${ }^{10}$ Hazma Eroğlu, tdare Hukuku, Ankara, 1984, s. 100.

${ }^{11}$ Ismet Giritli-Tayfun Akgüner, Idare Hukuku Dersleri, c. I, Istanbul, 1985, s. 96. 
olamazdi. Türk Anayasa sistemi de yasama yetkisinin, milletin seçilmiş temsilcileri dışındaki organlar tarafından kullanılmasına engeldir ${ }^{12}$.

1982 Anayasasi'nın TBMM'nin görev ve yetkilerini düzenleyen 87. maddesine Bakanlar Kurulu'na "belli konularda" KHK çıkarma yetkisi verilebilmesine ilişkin açık bir hüküm konmuş ve bu husus yasama yetkisi içinde yer almıştır. Bu sẹbeple 1961 Anayasası dönemindeki bu tür tartışmalara, bu şekilde çözüm getirilmiştir. Áslında 1961 Anayasasi'nın yasama yetkisinin devredilmezliği prensibi ile KHK çıkarma yetkisine yer veren 64. maddesi çatışma halinde değildir. Buna göre asıl yasama yetkisinin devredilmezliği genel, KHK çıkarma yetkisi ise daha özeldir ${ }^{13}$. Bu nedenle, KHK çıkarma yetkisi, yasama yetkisinin devredilmezliği prensibinin istisnasını oluşturur ve bu yetkinin aslî oluş kuralı çiğnenmez ${ }^{14}$.

Eğer yasama yetkisinin devredilmezliği ve KHK çıkarma yetkisine ilişkin anayasal kurallar arasında çatışmanın varhı̆̆ kabul cdilirse, bu kurallardan birisinin yok sayılması gerekecektir. Ancak 1982 Anayasası'nda konuya 87. madde ile açıklık getirilmesi karşısında bu mümkün değildir. Üstelik, 1982 Anayasası'nın yasama yetkisinin devredilmezliği ilkesi ile ilgili 7. maddesindcki KHK çıkarma yetkisinin saklı tutulduğuna dair ifadenin ${ }^{15}$, sonradan Anayasanın ilgili maddelerinde yer alması ve gereksiz tekrar olmaması için bu maddeden çıkarılması da KHK'nin istisnai bir yetki olarak yasama yetkisinin devredilmezliği ile çatışmadığını göstermektedir. 1961 Anayasası açısından duruma bakılıp iki kural arasında çatışma bulunabilcceği iddia olunursa, bu sefer KHK çıkarma yetkisinin yasama yetkisinin devredilmezliği kuralına nazaran sonraki tarihli bir anayasa kuralı olduğu düşünülebilecek ve bundan belki de yasama yetkisinin devredilmezliği prensibinin zımnen yok sayılması gerektiği gibi çok garip ve kabul edilemez bir sonuç ortaya çıkabilecektir.

Nitekim, 1982 Anayasası'nın görüşülmesi sırasında Anayasa Komisyonu Sözcüsü KHK'nin, "... çok acele hallerde hükûmetin elinde uygulanacak 'scri seri bir kural olmadığı için acele olarak çıkarılmak için..." öngörüldü̈̆ünü ifade etmiştir. Anayasa Komisyonu Başkanına göre ise "... KHK ... yasama meclisinin acil bir durumda kanun yapmak için geçecek sürede çıkartacağı kanunun ihtiyacı halledilecek meseleyi çözmeyeceğine, o zaman çok geç kalınacağı endişesinden kaynaklanan bir müessesedir ve bu müessese bunun için konmuştur." ${ }^{16}$.

Bilgen KHK'nin "belli konularda", yetki kanununda belirlenen amaç, kapsam ve ilkelerle çıkarılması ve çıkarıldıkları gün TBMM'ye sunulmaları ve TBMM'de

${ }^{12}$ Lütfi Duran, "Kanun Hükmünde Karamame", Amme Idaresi Dergisi, c. VIII, s. 2, Ankara, 1975, s. 3; Ergun Ozbudun, "1961 ve 1982 Anayasalarında Kanun Hükmünde Karamameler" Anayasa Yargısı, Ankara, 1986, s. 229, dp. 2.

13 Ergun Ozbudun, Türk Anayasa Hukuku, Ankara, 1986, s. 198, 199; Ózbudun, 1961 ..., s. 229.

${ }^{14}$ Teziç, a.g.e., s. 12; Kuzu, Türk..., s. 367.

15 Gerekçe için bkz. Attila Ozer, Gerekçeli ve 1961 Anayasasıyla Mukayesell 1982 A nayasası, Ankara, 1984, s. 51.

${ }^{16}$ Danışma Meclisi Tutanak Dergisi, c. IX, birleşim, 137-146, yasama yılı. 1, s. 152,153 . AMKD, sy. 29 , c. I, s. 331 'den naklen. 
onaylanarak ya da değiştirilerek kabul edilmesi ya da reddedilmesi gibi sebeplerle "kanunilik ilkesi"ne aynlık teşkil etmediğini belirtirken ${ }^{17}$, aslında yasama yetkisinin devredilmezliğine aykırılık oluşmadığını kastẹer görünmektedir.

Şu halde, (aynı zamanda) bu açıklamaların ışığında denilebilir ki, KHK'lere yasama organının kanun yapmasındaki gecikmelerden doğacak zararlanın önlenmesi için ihtiyaç duyulmaktadır.

Gerçekten, kanun tasan ve tekliflerinin yasama organının komisyonlanında ve genel kurulunda gündeme alını sıraya konulması ve görüşülmesi çok uzun süreler almaktadır. Yasama organının kendi işleri ve yürütmeyi denctlemesi gibi görev ve yetkileri de düşünülecek olursa, bu zaman daha da uzamaktadır. Kanun kabul edilse bile Cumhurbaşkanı'nın imzalaması ya da yasama organına tekrar görüsülmek üzere gönderilmesi, doğal olarak süreyi daha da uzatmaktadır. Bu gibi sebeplerle ${ }^{18}$ ortaya çıkan gecikmenin kamu yararına uygun olmaması ve ivedi durumlarda bir düzenlemeye ihtiyaç duyulması dolayısıyla KHK düşünülebilecck bir çözüm olmaktadır.

Yürütme organının parlamentoda yeterli desteği sağlaması ve gerekli çözümlerin anında üretilebilmesi de mümkün olabilir. Ancak, yasama organının tatil gibi sebeplerle çalışmadığı zamanlarda yine gecikmelerin olabileceği muhakkaktır. Kaldı ki, çalışma halinde bile yukarıdaki şekilde meydana gelen gecikmeler her zaman olabilecektir.

Teknik yönü olan ve uzmanlı̆̆ı gerektiren düzenlemelerde yönetime yetki verilmesi kamu hizmetinin etkinliğini daha da artırabilir.

KHK, -yukarıda değinildiği gibi- yürütme organının güçlendirilmesi yollanından birisidir ${ }^{19}$. Aslında KHK çıkarma yetkisi verilmesi daha çok parlamenter sistemlerde görülü̈r. Çünkü katı kuvvetler ayrılığına bağı başkanlık rejimlerinde yasamanın yürütmeyi KHK çıkarmak gibi bir yetki ile güçlendirmesi ve yetkilendirmesi, bu tür kuvvetler ayrılığının doğasına aykırıdır. Buna göre, yasama ve yürütmenin belli oranlarda karşıllıklı ilişkileri olan parlamenter sistemin özellikleri içine diğer özelliklere ck olarak, yasama organı tarafından yürütmeye bir kanunla belli konularda KHK çıkarma yetkisi verilmesi de sayılabilir, denirse kanaatimizce hatalı bir ifade kullanılmış olmaz. Şu halde denilebilir ki KHK kurumu, yukanda bclirtilenler çerçevesinde, parlamenter rejimin 20 tanımına katkı sağlayabilecek ve bu sistemin özellikleri arasında sayılabilecek bir kurumdur.

17 Pertev Bilgen, Idare Hukuku Ders Notları, Istanbul, 1985, s. 215.

${ }^{18} \mathrm{Bu}$ nedenler hakkında geniş bilgi için bkz. Kuzu, Türk..., s. 174 vd.

${ }^{19}$ Tan, a.g.e., s. 33; Duran, a.g.e., s. 3.

${ }^{20}$ Parlamenter sistem hakkında bilgi için bkz. A. Şeref Gözübüyük, Anayasa Hukuku, Ankara, 1986, s. 26 vd. 
KHK hukuksal niteliği bakımından kanun kuvvetinde ve etkisindedir. Anayasa Mahkemesi'nin bir kararında da bu belirtilmiştir ${ }^{21}$. Bu nedenle KHK, kanun gibi genel ve soyut nitelikli kurallar içerir.

Kanunların genelliği ve soyutluğu, kişileri ya da somut olaylan değil, genel ve sonradan durumuna uyan herkese objektif olarak uygulanabilir nitelikli kurallan konu almasını ifade eder ${ }^{22}$. Şu halde subjektif nitelikli işlemler kanunun konusu olamaz. Genellik ve soyutluk bir bakıma eşitlik ilkesi ile de ilişkilendirilebilir ${ }^{23}$. Eşitlik ise aynı durumiann aynı kurallara tabi olmasını gerektirir ${ }^{24}$. Çünkü herkese, önceden konulan kuralların uygulanması aynı zamanda hukuk devletinin yani hukukun üstünlüğünün bir gereğidir.

Aynca, yapılmakta olan bir yargılamaya müdahale olacak şekilde de kanun çıkarılamaz. Çünkü böyle bir kanun yargı organlarına bir tür talimat vermck olarak degerlendirilebilir.

KHK'lerin kanun gibi genel' ve soyut nitelik taşımaları sebebiyle maddi (fonksiyonel-işlevsel) açıdan yasama işlemi olarak adlandırıılmaları mümkündür ${ }^{25}$. Ancak, KHK'ler hangi tür ozzellikleri taşırlarsa taşısınlar, bunlan yapan organın işlemi ve eseri olarak anılırlar. Bu bakımdan KHK'ler yapılıs şckli ve yapan organ bakımından yürütme organının düzenleyici işlemidirler ${ }^{26}$. Yalnız, bð̌yle olmakla birlikte KHK'lerin kanun değeri ve etkisi düşünülecek olursa, kullanılan yetkinin "özel nitelikli yctki olduğu ortaya çıkar. Bundan hareketle KHK'lere de "yönetimin özel nitelikli düzenleyici işlcmi" denilebilir. Duran đa bu alanda "genişletilmiş" düzenleme yetkisinin varlığını kabul etmektedir ${ }^{27}$.

KHK'nin genel ve soyut nitelikli kuralları içermesi, bu kurumu parlamento kararlanndan da ayınr. Çünkü parlamento kararlanı daha çok yasama organının iç ve diğer organlarla olan ilişkilerini ilgilendirir ${ }^{28}$.

Yasama ve yürütme organının karşılıklı ilişkileri ve konuları bakımından KHK'nin temeli ve dayanağı hakkında çeşitli görüşler ileri sürülmüştür.

21 Omeğin,' Anayasa Mahkemesinin 06.10.1993 tarihli ve e. 1993/32, k. 1993/32 sayılı kararı, AMKD, sy. 29, c. I, Ankara, 1994, s. 353. Aynı içerikli, Danıştay 8. Dairesinin 07.06.1990 tarihli ve e. 811, k. 690 sayılı karan için bkz, Bilgen, 214.

22 Ozbudun, Türk..., s. 165 vd; Kanunların genellik ve soyutluğu hakkında tartışmalar için bkz. Turan Güneş, Türk Pozitif Hukukunda Yürütme Organının Düzenleyici Işlemleri, Ankara, 1965, s. 12 vd.

${ }^{23}$ T. Bekir Balta, Idare Hukukuna Giriş, c.I, Ankara, 1968/70, s. 82.

${ }^{24}$ Bununla ilgili olarak Danıstay Idari Dava Daireleri Genel Kurulu'nun 05.11.1982 tarihli ve e. 346, k. 410 sayı̀ kararı için bkz. Bilgen, 258.

25 Sağlam, s. 266; Ozbudun, Türk..., s. 297. Ayrıca, dp. 21 'deki Anayasa Mahkemesi kararı.

${ }^{26}$ Lutfi Duran, Idare Hukuku Ders Notları, Istanbul, 1982, s. 474.

${ }^{27}$ Duran, a.g.e., s. 474 , vd. KHK'nin "sui genesis" olduğu konusunda: Sağlam, a.g.e., s. 265; Teziç, a.g.e., s. 13.

${ }^{28}$ Ozbudun, Türk..., s. 180 . 
Bu konuda ileri sürülen bir görüşe göre KHK'nin dayanağını, yasamanın yürütmeye yaptığ yetki devri oluşturmaktadır 29 .

Bir kere bir organa verilen yetki, (bu organ var iken) başka bir organa devredilemez. Çünkü bu organlara kendi adına siyasî iktidan kullanma yetkisini millet vermiş; yetkileri kullanacak organlar ve bu yetkinin kullanılıs şekli Anayasa'da belirtilmiştir. Dolayısıyla, millet adına (vekaleten) kullanılan yetkinin (yine vekaletle) başka birisine ya da organa devri uygun değildir.

Ikinci olarak, yürütmeye KHK çıarma yetkisi verildiği zaman KHK ile düzenlenebilecek konularda yasamanın yetkisi kesilmemektedir. Yani yasamanın KHK ile düzenlenecek konularda da yetkisi her zaman kesintisiz devam etmektedir. Üstelik, çikarılan KHK'ler yasama organına sunulmakta ve bu organ, KHK üzerinde iradesini ortaya koyarak kanunlaşurmaktadir.

Üçüncü olarak; daha çok özel hukuk alanında görülen vekalet, vekil olarak seçilen kişinin de olumlu iradesini gerektirir. Kabul olmayınca vekalet oluşmaz. Halbuki burada biraz daha farklı bir durum vardır ${ }^{30}$.

Yürütmenin KHK çıkarma yetkisini, özellikle yasama yetkisinin devri görüşünün etkisiyle uzun zaman içinde oluşan bir tür "Anayasa geleneğine" dayandırmak da kabul edilemez. Çünkü bir hukuk kuralına aykırı gelenek olamaz ${ }^{31}$ ve uygulanamaz ${ }^{32}$.

Bir başka görüş̧e göre, dayanağı, yürütme organının işlemlerinin kanuna bağımlılı̆̆ı prensibinin kısmen askıya alınmasına bağlamak gerekir ${ }^{33}$. Halbuki bőylece, yürütme işlemlerini normlar hiyerarşisinde kanunların üzerine ya da eşitine çıkarmak sőzkonusu olabilecektir. Yani kurallar hiyerarşisi denilecektir. Yasama organı da bir nevi yok sayılacak ve kapalı bir kuvvetler birliğinden sözedilebilecektir. Bir yazara göre hukuk devletinin varolabilmesi için yasama, yürütme ve yargı erklerinin birbirinden ayrılması gerekir $^{34}$.

Bir başka görüşe gơre KHK çıkarma yetkisini, yasamanın yürütmeye verdiği önceden kabullenmeye ve tastike ilişkin bir güvenceye dayandırmak gerekir ${ }^{35}$. Bu düşünce kabul edilecek olursa, KHK'lerin çıkanıldıktan sonra yasama organına sunulması, yasama organının bir kanunla bu KHK'yi onaylaması, değiştirmesi veya reddetmesi gereklerinin hepsi hiçe sayılmıs, olacaktır. Üstelik bu durumda yürütmenin çıkardığı

${ }^{29}$ Server Tanilli, Devlet ve Demokrasi, Istanbul, 1985, s. 411; Kuzu, Türk..., s. 192 vd.

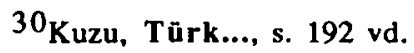

${ }^{31}$ A. Şeref Gözübüyük, Hukuka Giriş ve Hukukun Temel Kavramları, Ankara, 1978, s. 45; Giritli-Akgüner, a.g.e., s. 96.

32 Kuzu, Türk..., s. 204-208.

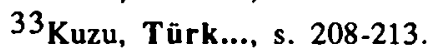

${ }^{34}$ A. Şeref Gözübüyük, Yönetim Hukuk, Ankara, 1983, s. 23.

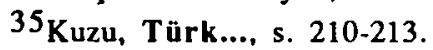


hukuka aykırı tüm işlemlerin de varlığının kabul edilmesi gerektiği gibi garip ve kabul edilemez bir sonuç ortaya çıkacakur.

Diğer bir düşünceye göre, KHK çıkarma yetkisinin temelini, yasama organının kendi alanında bulunan bazı yetkileri yürütme organı alanına aktararak yürütmenin yetkisinin arturılması ve genişletilmesi teşkil eder ${ }^{36}$.

Yürütmenin yetkisinin bu şekilde arırılması ve genişletilmesi, artırılmış ve genişletilmiş yetki ile çıkardığı karamamelerine kanun değeri vermiş olacaktır. Bunun gibi, bu tür karamamelerle, kanunlar kaldırlabilecek, değiştirilecek veya konulabilecektir. Bu kabul edilemez ${ }^{37}$; çünkü yasama yetkisi aslî bir yetkidir ve yürütmeye bu suretlè genişletilmiş veya artırılmı̧ yetki vermenin anayasal dayanağı yoktur. Yetki artırımı teorisinin, yetki arunıması yoluyle çıkarılmış kararnamenin varlığı ile geçerlilik kazandığını ${ }^{38}$ söylemek de aynı eleştirileri kaldırmaz. Kaldı ki bu durumda da kanunlann kapalı olarak yürüttme kararnamesi ile değiştirilebilecek duruma geldiği ve kararname seviyesine indiği düşünülebilecektir.

Yürütmenin KHK çıkarma yetkisinin temelini yasama tarafından yürütmeye verilen bir "iş" ve "görev" anlayışına dayandırmak ${ }^{39}$ da isabetli olmaz. Bu durumda yasamanın yürütmeye bir emir ve dircktif verme yetkisi tanınmıs demektir. Bu bilhassa 1982 Anayasasina göre mümkün değildir. Çünkü yürütme hem görev ve hem de yetkidir. Diğer taraftan görev verme bir anlamda daha çok "bağlı yetki" çerçevesinde yürütmeden uygulama istemek olur ki, bu tür uygulamalar için yönetimin daha alt dereceli düzenleyici işlemler yapma yetkisi zaten vardır. Halbuki KHK, yönetime ihtiyaçlara göre kanun seviyesinde düzenleyici işlem yapıp uygulayabilmek için verilir.

Erklerin ayrımı ilkesi, yasamanın ve yürütmenin birbirlerine görev ve iş verebilmelerini engeller niteliktedir. Yürütme erki görev ve yetkisini Anayasa'dan alır.

1982 Anayasası'na göre -1961 Anayasası'nda olduğu gibi-yasama órganının, yani TBMM'nin Bakanlar Kurulu'na KHK çlkarma yetkisi verip vermemekte taktir yetkisi bulunmaktadır. Yasamanın, yürütmeye bu yetkiyi vermesi anından itibaren, bu konularla ilgili olarak kanun yapmak yetkisi kesilmemektedir. Yani TBMM aynı konularda her zaman kanun çıkarmaya ve verdigi yetkiyi geri almaya yetkilidir. Yetki verme işlemi de 1982 Anayasası'nın 91. maddesindeki şartlara ve şekle uygun olacak ve çıkarılacak KHK'ler de TBMM'nin iradesine yine aynı maddede belirtilen şekilde sunulacak; TBMM de bu KHK ile ilgili iradesini ortaya koymaya yetkili olacaktır.

Şu halde denilebilir ki, 1982 Anayasasinın 91. maddesi hükmüne göre KHK'nin dayanağıını, yasama organının yürütmeye, bu madde sınırlan, şekil ve şartları çerçevesinde "yetki vermesi" oluşturmakta; alınan yetki ile yürütme organı tarafından çıkarılan KHK, kanun etkisi ve kuvvetinde özel nitelikli düzenleyici bir işlem olmaktadır.

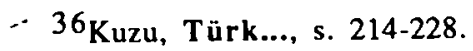

${ }^{37}$ Duran, a.g.e., s. 475.

${ }^{38}$ Buna şarth yetki artırımı adı verilmektedir. Bkz. Kuzu, Türk..., s. 224 vd.

${ }^{39}$ Sağlam, a.g.e., s. 266. 
Nitckim Anayasa mahkemesi bir kararında ${ }^{40}$, KHK çıkarılmasına yetki verilmesinin yasama yetkisinin devri olmadı̌̆ını, yalnızca yasama organının yetki kanununda belirlendiği konu, amaç, kapsam ve ilke sınırları içinde düzenleme yetkisinin yürütme organınca kullanılması olduğunu belirtmiştir.

Tüm bu bilgilerden sonra özet olarak bir tanım yapılacak olursa; KHK, yasama organınca Bakanlar Kurulu'na verilen yetkiye dayanarak ve bu yetki sınırları içinde kalarak, (yasama organının yetkisi devam etmek kaydıyla) Bakanlar Kurulu'nca çıkarılan, şekil olarak Bakanlar Kurulu'nun diğer kararnamelerine benzeyen, fonksiyonel (maddîişlevsel) bakımdan ise genel ve soyut bir "kural-işlem" obzelliği taşıyan, hukuksal değeri itibariyla kanun etkisinde ve kuvvetinde olan, "özel nitelikli düzenleyici bir işlem"dir.

KHK'nin çeşitli boyutlarının bẹlirlenmesine ve daha iyi tanımlanabilmesine katkı sağlayabilecek bilgilere bundan sonraki ycrlerde yer verilmiştir.

\section{B- Yönetimin Düzenleyici İşlemleri ve KHK}

Yönetimin düzenleyici işlemleri, yönetimin, yasaların yürütülmesi amacıyla, düzenleme yetkisine dayanarak yasa ile kendisine verilen alanı düzenlemek için, bazan kural, bazan şart ve bazan da bireysel işlem özelliği taşı şekilde verdiği tüm emirleri ve aldığı kararlan ifade eder.

$\mathrm{Bu}$ ifadeden de anlaşılacağı gibi, düzenleme yetkisi, yürütme yetkisinin bir parçasını oluşturur. Yürütme yetkisi de yönetimin yetkileri arasındadır ${ }^{41}$. Çünkü yürütme, bir konuda öncelikle karar vermek ve bu kararlar yönünde uygulama yapmák sureti ile kamu hizmetlerini yerine getirmektedir ${ }^{42}$. 1961 Anayasa'sının yürütme görevi ile ilgili maddesinin gerekçe kısmında, yürütmenin kanunların uygulanması demek olduğu belirtilmiş ve Fransa ve ltalya ile karşılaşırma yapılarak, Anayasa'mıza göre kanun olmadan düzenleyici işlemin yapılamayacağı yönünde açıklamalarda bulunulmuştur ${ }^{43}$. Bu durumda 1961 Anayasası'na göre de yürütmenin düzenleme ve uygulamadan ibaret olduğu söylense yanlış olmayacaktır.

Yönetim düzenleme yetkisini yaparken taktir yetkisine dayanır ${ }^{44}$. Ancak bağlı yetki de düzenleme yetkisini kullanmayı gerektirir. Çünkü, yönetimde, kanunun uygulanması için çoğunlukla kanunla uygulayıcı arasına üstlerin düzenleyici işlemleri adeta bir emir özelliği taşır nitelikte girer ${ }^{45}$.

${ }^{40}$ Anayasa Mahkemesi'nin 16.03 .1993 tarihli ve e. 26 , k. 28 sayılı kararı, AMKD, sy. 29, c.I, s. 332 .

41 Gözübüyük, a.g.e., s. 183.

42 Waldemar Besson - Gottnard Jasper, Das Leitbild Der Modernen Demokratie, Bonn, 1990, s. 49; Gözübüyúk, a.g.e., s. 183, Güneş, a.g.e., s. 44, 45; Kuzu, Anayasa..., s. 29 vd.

43 Ozer, a.g.e., s. $55,56$.

${ }^{44}$ R. Cengiz Derdiman, "Kamu Yönetiminde Yetki Genişliği", Amme Idaresi Dergisí, c. 28 , sy. 4. Ankara, 1996 , s. 73 ; Günes, a.g.e., s. 88 ; Balta, a.g.e., s. 85.

45 Derdiman, a.g.e., s. 75; S. Sami Onar, Idare Hukukunun Umumi Esasları, c. I, Istanbul, 1960, s. 476. 
Aslında hukuk kaynaklanının kendisine bıraktığı konuları bir takım objektif kurallarla düzenlemek yőnetimin aynı zamanda odevidir. Diğger bir deyişle, düzenleme yetkisinin kullanılması gereği ile başvurulması adeta zorunlu hale gelen taktir yetkisinin, yơnetim tarafından her olay için ayn ayrı düzenleyici işlem yapması yerine, benzer olaylar için eşit uygulamalara esas olacak onnceden yapılmı̧ genel ve soyut düzenlemelere başvurulması zorunludur 46 .

Gơrüldüğü gibi yơnetimin işlemleri soyut, herkese uygulanabilir bir işlem olabildiği gibi, belki kişilere ya da olaylara yơnelik sübjektif işlemler şeklinde de olabilmektedir.

Yönetimin genel ve soyut işlemlerinin yasama işlemi niteliğini taşıdığını belirten görüşlere rastlamak mümkündür 47 . Örneğin 1949 tarihli Alman Anaýasası'nın 80. maddesi, yơnetimin, şartları bu maddede yazılı sınırlarla tüzük çıarabileceğini belirtmiştir. - Alman doktrininde de yürütmenin bağımsız bir düzenleme yetkisinin olmadığı savunulmuştur. Buna göre ${ }^{48}$ yürütme kendiliğinden kural koyamaz, yasamanın çizdiği sınırlar içinde uygulama yapar ${ }^{49}$.

Bize göre düzenleme, yürütmenin asıl gơrevidir; yürütmeden ayrılamaz. Çünkü yönetim, belli konularda faaliyetlerini yürütürken önceden, neyi, nerede, nasıl kullanacağını, hizmeti ne şekilde, hangi personelini çalıştırarak yapacă̌ını planlamak zorundadır. Çünkü planlama, aynı zamanda karar vermek ${ }^{50}$ ve verilen kararlarla personeli hizmete yơneltmek demektir. Ústelik birden fazla faktörün birleştiği yönetim faaliyeti, bu faktőrlerin uyumlu bir biçimđe amaca yöneltilebilmesi için önceden planlamayı ve dolayısiyla karar vermeyi zorunlu kalar 51 .

Yürütme yetkisine sahip yönetimin -yukandaki sebeplerle- düzenleme yetkisinin asıl yetki olduğu söylenebilir. Ögretide de genellikle düzenleme yetkisinin yürütmenin asıl yetkisi olduğu vurgulanmaktadır 52 . Yani kuvvetler birliği rejiminde dahi, ölçüsü bu sistemin ozellił̧ine gơre az ya da çok, belli bir oranda, yơnetimin aslî düzenleme yetkisi vardir.

${ }^{46}$ Günes, a.g.e., s. 88; Derdiman, a.g.e., s. 75 ; Onar, a.g.e., s. 275 vd. Anayasa Mahkemesi düzenleme yetkisini hukukun temel ilkelerinden saymaktadır. Bkz. 19.03.1987 tarihli e. $86 / 5$, k. $87 / 5$ say1l karar, Bilgen, a.g.e., s. 273 'den naklen. Güneş düzenleme yetkisinin yönetimin normal yetkisi olduğunu söylüyor. s. 49.

${ }^{47}$ Kuzu, A nayasa..., s. 29.

48 Onar, a.g.e., s. 276.

${ }^{49}$ Besson-Jasper, a.g.e., s. 49.

${ }^{50}$ Turgay Ergun - Aykut Polatoğlu, Kamu Yönetimine Giriş, Ankara, 1984, s. 216. Albert Meier, Rationelle Führung Und Leltung In Der Unternehmung, Stuttgart, 1957, s. 12 vd.

51 Meier, a.g.e., s. 12, 19.

52 Onar, a.g.e., s. 276; Güneş, a.g.e., s. 77. 
Yönetimin ${ }^{53}$ düzenleyici işlemleri arasında; tüzük, yönetmelik, kararnameler ve emir, genelge, sirküler gibi "diğer düzenleyici işlemler" 54 yer almaktadır.

Üzerinde kısa bilgi verilen düzenleyici işlemlerle KHK arasında benzerlikler ve farklılıklar bulunmaktadır.

KHK'nin yŏnetim tarafından düzenleyici işlem olarak yapılması, şekil ve usul bakımından Bakanlar Kurulu'nun diğer karamameleri gibi olması, düzenleyici işlemlerle benzer yönlerini ortaya koymaktadır.

Buna karşılık KHK ile düzenleyici işlemler arasında şu farklara dikkat çekilebilir.

KHK fonksiyonel bakımdan yasama işlemi niteliłinde kabul edilmektedir ${ }^{55}$. Düzenleyici işlemler ise, yürütmenin aslí görev ve yetkisi içindedirler. Bu bakımdan once de söylendiğ̣i gibi, KHK'leri, yönetimin özel nitelikli düzenleyici işlemi olarak adlandırmak mümkündür.

KHK'ler, yasama yetkisinin devredilmezliğinin istisnasını oluştururlar ve ivedi ve zorunlu durumlarda çıkarılırlar. Düzenleyici işlemlere de ivedi ve zorunlu durumlarda ihtiyaç duyulduğu yönündeki düşüncelere rastlansa $\mathrm{da}^{56}$ düzenleyici işlemler, ivedi ve zorunlu durumlara sınırlı değildirler ve yürütmenin aslî nitelikli düzenleme yetkisinden kaynaklanırlar.

KHK'ler yetki kanunu çençevesinde çıkarılan, kanun değerinde ve kuvvetinde idari işlemlerdir. Düzenledikleri konular kanun gibi uygulanırlar ve yetki kanunu sinırları içinde kanunlarda değişiklik yapabilirler. Düzenleyici işlemler ise kanunda belirtilen işleri ya da kanunun uygulanmasını gösteren kurallar içerirler. Bu bakımdan kanuna dayanırlar. Yönetim, çıkardı̆̆ı KHK'ye dayanarak, bunun uygulanması için düzenleyici işlem yapabilir. Sonuçta kanụn ya da KHK'nin "düzenlenmesinden" bahsedilebilir.

Burada bir parantez açarak, kısaca, yőnetimin kanunun düzenlemediği bir alanda Anayasa'ya dayanarak düzenleme yapıp yapamayacağı konusuna değinmek gerekecektir.

1961 Anayasası'nda yürütmenin kanunlar çerçevesinde yerine getirilen bir görev olduğu kuralına dayanan bazı yazarlar, kanunun bulunmadı̌̆ bir alanın yöetim tarafindan düzenlenemeyeceğini ileri sürmüşlerdir ${ }^{57}$. Buna karşılık aynı Anayasa döneminde,

${ }^{53}$ Idare hukukunda yer alan yürütme ve yönetim ayrımı yapılmaktadır. Ancak, biz yönetimi, yürütmeyi de kapsayacak şekilde kullandik.

${ }^{54} \mathrm{Kuzu}$, Anayasa..., s. $75,76$.

$55_{\text {Bkz. dp. } 25 .}$

${ }^{56}$ Tekin durumlar, parlamentolann yavaş çalışması ve her konuyu en ince ayrıntısına kadar hükmü bulunmasının mümkün olmaması cuúnkủ bunların bu durumda değişen ફartların gerisinde kalma ihtimaline sahip olmaları gibi nedenler de düzenleme yetkisinin temeli içinde sayılmaktadır. Bkz. Kuzu, Anayasa..., s. 41 vd; Güneş, a.g.e., s. 52 .

57Duran, a.g.e., s. 37. 
Anayasa'nın üstünlügü prensibi gerełince, Anayasa'nın kanunlar gibi uygulanabileceği savunulmuştur ${ }^{58}$.

Ancak 1982 Anayasası'nın yürütmeye sadece "görev" değil aynı zamanda "yetki" olarak yer vermesi, yönetimin yasallığı prensibini düzenlediği 123 . maddesinin gerekçesinde kanun olmayan bir alanda anayasaya göre düzenleme yetkisinin kullanılabileceğini belirtmesi ${ }^{59}$ gerekçcleri ile, yönctimin, kanunun düzenlemediği bir alanda doğrudan Anayasa hükümlerini uygulayabileceği görüşü ileri sürülmüş̧ür60.

Anayasa'nın kanunla düzenlenmesini öngördüğü konular için düzenleme kanuna dayanmalı, yassalık ilkesi bu şckilde tamamlanmalıdır ${ }^{61}$. Anayasa Mahkemesi'nin bir kararında ${ }^{62}, 1961$ Anayasası'nın 118. maddesindeki yöntem şartlanını yönetimin doğrudan uygulayabileceğini belirtmesi de aynı görüşü benimsediği yönünde değerlendirmeye değerdir.

KHK'ler çıarıldıktan sonra TBMM'ye sunulurlar ve TBMM'nin komisyonlarında ve genel kurulunda görüşülürler. Halbuki düzenleyici işlemlerin TBMM'le sunulmalarına ve dolayısı ile görüşülmelerine gerek yoktur. Bazı kararnamelerin TBMM'ne çıkarıldıkıan sonra bilgi olarak sunulması ${ }^{63}$. bunlan KHK gibi algılamaya yetmez.

KHK'ler kanunun koyduğu genel esaslar çerçevesinde çıkarılan "kaide kararnameler"den de farklıdırlar; çünkü bunlar da düzenleyici işlem niteliğini taşırlar. Bu şekilde çıkarılan düzenleyici işlemlerin adeta kanun özelliği taşıdığı ve-dolayısıyla Anayasa'ya aykırılığı iddialarını Anayasa Mahkemesi, yönetime kanunun koyduğu genel esaslar çerçevesinde geniş bir düzenleme yetkisinin tanınmasında Anayasaya aykırılık görmeyerek reddetmiştir ${ }^{64}$.

Bakanlar Kurulu dışındaki yönetim kademeleri tarafından yapılan düzenleyici işlemlerin yetkiyi kullanan makam bakımından da farklarının olduğunu bclirımek yerinde olacaktur.

58 tlhan Arsel, Türk Anayasa Hukukunun Umumi Esasları, 1. Kitap, Cumhuriyetin Temel Kuruluşu, Ankara, 1965, s. 152'den nakleden: Tekin Akıllığlu, Yönetim Önünde Savunma Hakları, Ankara, 1983, s. 83, 84.

59 Ozer, a.g.e., s. 470 .

${ }^{60}$ Eroğlu, a.g.e., s. 47; Derdiman, a.g.e., s. 70.

61 Akılhığlu, a.g.e., s. $85,86$.

62 Anayasa Mahkemesi'nin; 1-) 20.05 .1963 tarihli ve e. 174, k. 115 sayll, 2-) 22.05.1963 tarihli ve e. 203, k. 123 sayılı kararları, Akılhığlu, a.g.e., s. 85, 85, dp. 300,301 'den naklen.

${ }^{63}$ Milli Korunma Kanunu uygulaması bu şckilde olacaktır. Bkz. Kuzu, Türk..., s. 136 vd, 282.

${ }^{64}$ Anayasa Mahkemesi'nin 28.03.1963 tarihli ve e. 4, k. 71 sayılı kararı, Kuzu, Türk..., s. 367'den naklen. Ayrica benzer olarak bkz. 05.10.1991 tarihli ve e. 90/29, k. 91/37 sayılı kararı, Bilgen, a.g.e., s. 273. 
Bir görüşe göre KHK nitelikçe tüzükten farklı deģildir 65 . Bakanlar Kurulu KHK ile dilediği kanun hükmünü değiştirebilseydi ya da kaldırabilscydi, o zaman yasama işleminden bahsetmek gerekecekti.

Yasama yetkisi kanun koymak, değiştirmek ve kaldırmak yetkilerini içerir. KHK'de kanun kuvvetindedir ${ }^{66}$. Dolayısıyla bu nitelikleri sebebiyle KHK'nin tüzükten farkı olduğu söylenebilir. Üstelik tüzük ile KHK arasınđa diğcr bazı farklar da vardır. Örneğin tüzüğün çıkarılmadan evvel danışlayca incelenmesi gerekir.

KHK'nin yasama organı önünde Bakanlar Kurulu'nun kanun tasansına ilişkin kararnamesi olarak düşünülmesi de kabul olunamaz ${ }^{67}$. Çünkü KHK çıkarıldığı anda hukuk alemine kanun kuvvetinde etki etmektedir. TBMM'nin bunu değiştirerek kabul etmesi ya da reddetmesi hallerinde, ret ve değişiklik kararlan, yayımlandıkları andan itubaren hüküm ifade etmektcdir 68 .

\section{KHK'nin Yönetim Ile İlgisi}

Belirlenen amaçlar çerçevesinde yürütülen bir faaliyet olarak yönetimin, KHK ile iki türlü ilgisi ortaya konulabilir.

Yönetimin KHK ile ilgili olduğu yönlerden birincisi KHK'nin çıkarılması, ikincisi de yürütülmesidir.

Yönetimin KHK ile öncelikli ilgisi KHK'nin çıkarlmasında kendini gösterir. Şöyle ki; yönetim, yasaya bağlılık gereğince, ivedi ve zorunlu durumlarda, yetki almışsa, bir alanı bu yetki sınırlan içinde KHK ile düzenleyebilir.

Yönetim KHK'yi yaparken, ihtiyaçlanı nazara alır ve yönetimin bünyesindeki uzmanlardan yararlanabilir. Böylece ihtiyaçlara göre bclirlenmiş, teknik yönden de tamamlanmış bir hukuksal metin ortaya çıkar. Bunun gibi kanunlar da yönetimin ihtiyaçlan sebebiyle çıkanlmasına ihtiyaç duyulan, konunun uzmanlarınca da gerektiğinde görüşler alınarak yapılan hukuksal metinlerdir. Kanunların çıkanılması sırasında da yönetim tasarıları ve görüşleri ile belki de birinci derecede etkindir.

Yönetimin, çıkardığı KHK'yi yürütebilmesi için daha önce değinildiği gibi düzenleyici işlemler yapması hem uygun hem de gerekli olabilir.

\section{II- KHK ILE ILGISI BAKIMINDAN YETKI KANUNU}

\section{A- KHK'nin Geçerlilik Şartı Olarak Yetki Kanunu}

1982 Anayasası ile Yasama yetkisinin devredilmezliği prensibinin istisnası olarak getirilen KHK çıkarma yetkisinin kullanılabilmesi için, yasamanın, yürütmeye, belli

${ }^{65}$ Duran, a.g.e., s. 474.

${ }^{66}$ Bkz. dp. 40. Ozbudun, 1961..., s. 228, 229.

${ }^{67}$ Teziç, a.g.e., s. 11, Kuzu, Türk..., s. 387.

68 Ozbudun, 1961..., s. 229. 
konularda KHK çıarabilmesiyle ilıgili "yetki vermesi" gereklidir. Bu yctkinin kanunla verilmesi gerektił̆i ise 1982 Anayasisı'nın aşağıya aynen alınan 91/2. maddesinde geçen "yetki kanunu" deyiminden anlaşılmaktadır. Su halde, yetki kanunu ile yetki verilmeden, yürütmenin, olağan dönemlerde KHK, çıkarması mümkün değildir.

1982 Anayasası'nın yetki karıunu ile ilgili hususları düzenleyen (ve burada aynen alınan) 91/2. maddesine göre;

"Yetki kanunu, çıkarılacak KHK'nin, amacını, kapsamını, ilkelerini, kullanma süresini ve: süresi içinde birden fazla kararname çıkarılıp çıkarılamayacağını gösterir."

Bu hükme göre kullanma süresi ile amaç, kapsam ve ilke konularında bazı değerlendirmelerin yapılması yerinde olacaktır.

Bir kere, hükümde geçen "kullanma süresi" deyiminin hangi kamu hukuku işlemi için ơngörüldüğ̈ü yeterince belirli dę̆ildir. Bu durumda kullanma süresi deyimi ya yetki kanununa veya KHK'ye aittir.

Bu konuda ilcri sürülebilecek ilk görüşe göre kullanma süresi, yetki kanununun kullanma süresini belirtmektedir. Bına göre çıkanlacak yetki kanunda, verilen yetkinin süresi belirtilmelidir. Ǒgretide genellikle benimsenen bu görüş ${ }^{69}$ kanaatimizce şu gerekçelere dayanabilir.

1- 1982 Anayasası'nın 9.1. maddesinin gerekçesinin incelenmesinden, Anayasa koyucunun, kullanma süresi konusurida 1961 Anayasası'ndan farklı bir sonucu amaçladığı ortaya çıkmaktadır ${ }^{70}$.

2- 1982 Anayasası hazırlauırken, çeşitli ülkelerin Anayasaları ile Anayasa metinlerimiz gözönünde tutulmuştur ${ }^{71}$. Incelenen Anayasalar içinde yer alan Italyan Anayasası'nın 77. maddesinde yer alan KHK'lerin geçerlilik süresine ait hüküm Anayasamıza aktanımamıştır. Söz konusu 77. maddeye göre KHK'ler yayımlandıkları tarihten itibaren 60 . gün içinde kánunlaşmadıklan zaman yayımmlandıkları günden başlayarak yürürlükten kalkmış olurlar. Ayrıca benzer bir düzenleme A.Ü. S.B.F. Ögretim Üyelerince hazırlanan Anayasa Önerisi'nde de vardır ve bu önerileri, 1982 Anayasası'nın hazırlanmasında yardımcı olmak üzere yasama organına sunulmuştur. Sözü geçen önerinin 64. maddesine göre de KHK'ler Cumhurbaşkanı veya en az elli milletvekilinin gerekçeli istemi üz.erine yayımı tarihinden başlayarak 15 gün içinde TBMM'de göruişülecektir ${ }^{72}$.

Tüm bunlar dolaylı da olsa KHK'nin kullanılma süresini ilgilendirdikleri halde 1982 Anayasası'na yansımamışlardır.

${ }^{69}$ Soysal, a.g.e., s. 337 ; Sağlam, a.g.e., s. 263. Bunlar (sadece) ornektirler.

${ }^{70}$ Gerekçe için bkz. Ozer, a.g.e., s. 374 .

${ }^{71}$ AUSBF Ŏgretim Oyeleri, Gerekçeli Anayasa Önerisi, Ankara, 1982, s. 84, 85.

72 Dal, a.g.e., s. $123,124$. 
3- Kuilanma süresi verilen yetkiye ait olmasayd, yukandaki 91/2 maddesinin son yanm cümlesinin bir anlamı kalmayacaku. Bu son yanm cümle, "süresi içinde birden fazla kararname çıkanılıp çıkarılamayacağının" belirtilmesini gerektirmekte ve kullanma süresinin verilen yctkiye ait olduğu izlenimini ortaya koymaktadır.

4- Tüm bunlardan başka, kullanma süresinin, verilen yetki için öngörülmediğini belirten hüküm yoktur.

Sőz konusu "kullanma süresi"nin KHK için öngörüldüğü, yani yetki kanununda KHK'nin kullanma süresinin belirtilmesi gerektiği yönünde ise şu gerekçeler ileri sürullebilir:

1- Her şeyden önce kullanma süresi deyiminin yetki kanununa ait olduğuna yani yetki kanununda, verilen yetkinin kullanılması süresinin belirtilmesi gerektiğine dair, hükümde bir açıklık yoktur. 1982 Anayasası'nın 91. maddesinin gerekçesinde kullanma süresi konusunda 1961 Anayasası'nın benzer hükmünün benimsenmesinin amaçlandığı ortaya çıkmaktaysa da yukandaki 91/2. madde hükmü bu amacı ifade etmekten uzakur. Halbuki, 1961 Anayasası'nda, kullanma süresinin verilen yetkiye ait olduğu çok açık ve anlaşılabilir bir şekilde ifade edilmiştir. Uygulanan (pozitif) hukuku, hükümler oluşturur. Gerekçeler de yoruma ve anlamaya yardımcı olurlar.

2- 1982 Anayasasi'nın 91/2. maddesi hükmü Türkçe dilbilgisi kurallarına göre incelendiğinde; "kullanma süresi"nin, fark gözetmeden, amaç, kapsam ve ilke ile birlikte sayılarak, bunlarla birlikte KHK'ye tamlandığ süresinin verilen yetkiye ait olduğunu söylersek, amaç, kapsam ve ilke için de muhtemelen aynı şeyi söylemek gerekecektir.

Bunun yanısıra, ifade de "gösterir" cyleminin yüklendiği özne olan "Yetki kanunu" deyimi, KHK'nin amacı, kapsamı ve ilkeleri gibi, aynı zamanda kullanma süresi ile tümlenmiş yani tamamlanmıştır. Bu durumda ifade "Yetki kanunu, ... KHK'nin, ... kullanma süresini... gösterir." biçiminde anlaşılmalıdır. Bunun aksine kullanma süresi verilen yetkiye ait olamaz; çünkü, bu durumda kullanma süresi gösterilecck nesne belirgin değildir. Üstelik KHK'nin kullanma süresinin belirtilmesinde o kadar belirgin sayılabilecek bir anlam düşüklügüü de görülmemektedir.

Söz konusu hükümde "çıkarılacak KHK'nin" kendinden sonra gelen amaç, kapsamı ilke ve kullanma süresi isimlerinden "virgül"le ayrılması, kutlanma süresinin verilen yetkiye ait olduğunu gőstermeye yetmediği gibi, bu virgülün, KHK ile kendisinden sonra yazılı isimleri bir birinden ayırmak gibi bir fonksiyonu vardır.

Nitekim 1982 Anayasasinın hazırlanmasında (Anayasa Komisyonunda) görev alan Prof. Dr. Kemal Dal, bir eserinde, "Yctki kanunu, çıkarılacak KHK'nin kullanılma süresini... göstermelidir." demek sureti ile, oğretideki genel eğilimin aksine, kullanma süresi belirtilmesi gereken kamu hưkuku işleminin KHK olması gerektiği görüşünü benimsemiştir ${ }^{73}$.

${ }^{73}$ Dal, a.g.e., s. 248. 
Bu değerlendirmeler göstermektedir ki, 1982 Anayasası'nın 91/2. maddesinin ifade tarzı itibarıyla, kullanma süresi göstcrilmesi gereken kamu hukuku işleminin (yetki kanunu veya KHK'den hangisi olduğunun) belirlenmesinde bir "ikilem" mevcuttur. Hükmün ifade tarzı, daha çok KHK'nin kullanılma süresinin belirtilmesi gerektiği şeklinde anlaşılmaya uygun görünmektedir. Gerçi Anayasa mahkemesi bir kararında ${ }^{74}$ "Bakanlar Kurulu'na verilen türevsel yetki, yasada öngörülen amaç, ilke, kapsam ve süre ile sınırlı bir yetkidir." demek sureti ile, kullanma süresinin verilen yetkiye ait olması gerektiği görüşünü benimsemiştir. Fakat, Yüksek Mahkemenin sırf kullanma yetkisini değerlendiren gerekçeli kararı mevcut olmadığı gibi, bu görüşün zaman içinde değişmesi de ihtimal dairesindedir.

Aslında Anayasa'nın hazırlanması sırasında yararlanılması için A.Ü. S.B.F. Ögretim Üyelerince verilen Anayasa Önerisi'nin 64. maddesinde kullanma süresinin verilen yetki için öngörülddügü gayet açı ifade edilmiştir ${ }^{75}$.

Surasını hemen belirtmek gerekir ki, kullanma süresinin KHK'ler için öngörülmesi halinde, tupkı Italyan Anayasası'nın 77. maddesinde olduğu gibi, KHK'nin geçerlilikleri sırasında oluşan hukuki durumların ve kazanılmış hakların geleceğinin Anayasa'mızda belirlenmesi uygun olacaktır.

Eğer kullanma süresinin KHK için öngörüldüğü ve dolayısıyla yetki kanunlarında KHK'lerin kullanılma sürelerinin belirtilmesi gerektiği iddia edilecek olursa, 1982 Anayasası'ndan sonra çıkanlan ve KHK'lerin kullanılma sürelerine yer vermeyen yetki kanunlan, verilen yetkinin sürelerini kendi içinde belirtseler de Anayasa'ya aykın duruma düşeceklerdir. 12.03.1986 tarihli ve 3268 sayılı; 09.04.1987 tarihli ve 3347 sayılı ${ }^{76}$; 24.06.1993 tarihli ve 3911 sayılı; 25.01 .1995 tarihli ve 4066 sayılı yetki kanunlannda, sadece, verilen yetkinin kullanılma sürelerinin belirtildiği görülmektedir. Bunlar sađecè ormektirler.

KHK, yönctim bilimi açısından bir plan, bir karar alma şeklidir. Amaç, kapsam ve ilke gibi hususların, gözetilecek sınırlar çerçevesinde ve gereklilikleri ölçüsünde, alınacak kararda yer alması mümküindür ${ }^{77}$. Kararların içinde amaçlar da belirlencbilir.

Şu halde, yetki kanunu, KHK'nin yapılması sırasında, Bakanlar Kurulu'nca gözetilecek amaçlari göstermelidir. Incelemeyc devam ettiğimiz. 91/2. maddede geçen amaç, kapsam ve ilke ile ilgili ifade de böyle anlaşılmalıdır.

Yukarıda belirtilenler doğrultusunda, denilebilir ki, içinde KHK çıkarılırken gözetilmesi gereken hususları belirtmeyen ve buna karşılık, kendisinin veya yetkinin veriliş amacını belirten kurallar içeren yetki kanunlannın da Anayasa'ya aykırılığı tartışılabilecektir.

${ }^{74}$ Anayasa Mahkemesi'nin 06.10 .1993 tarihli ve e. 32, k. 32 sayılı kararı, AMKD, sy. 29. c. I, s. 354.

75 AUSBF, 84, 85.

76 Aşkhan Doğan, Devlet Memurları Kanunu, Ankara, 1987, s. 214-216.

${ }^{77}$ Oğuz, Onaran, Örgütlerde Karar Verme, Ankara, 1971, s. 48. 
Bu bağlamda, yukanda değinilen 3911 sayılı kanunun "Bu kanunun amacı..." şeklinde yer alan 1. maddesi; aynı tür ifadeyi içeren 4066 sayılı kanunun 1. maddesi, Anayasada'ki ifadeden farklı olarak, KHK çıkarma yetkisi verilmesini amacını belirtmemektc; aksine, yetkinin veriliş amacını göstermektedir. Halbuki 3268 sayılı yetki kanununun 3347 sayılı kanunla değişik 1. maddesi, Bakanlar Kurulu'na KHK çıkarma yetkisinin veriliş nedenini ifade etmektedir.

Kullanma süresinin yetki kanunu için öngörülmesi amaçlanırsa; amaç, kapsam ve ilke ile ilgili olarak yukarıda söylediklerimizin ışı̆̆ında, ömeğin;

"Yetki kanununun, KHK çıkarılırken gözetilecck amaç ve ilkelerle, kapsama alınacak konulan ve verilen yetkinin kullanılması süresiyle bu süre içinde birden fazla karamame çıkarılıp çıkarılamayacağını belirlemesi . zorunludur."

şeklindeki ifade ikilemi ve anlam karmaşıklığını önleycbilecek niteliktedir.

Yetki kanunuda bulunması gercken hususlarla ilgili olarak 1982 Anayasası hükümleri, 1961 Anayasası hükümlerinden bazı farklılıklar göstermcktedir. 1961 Anayasası'nda yer alan, yetki kanununda yürürlükten kaldırılacak kanun hükümlerinin belirtilmesi ve KHK'de dayanağı oluşturan yetki kanununun gösterilmesi zorunluluğu getiren kurallar 1982 Anayasası'na alınmamışıtır. 1982 Anayasası'nda ise, 1961 Anayasası'ndan farklı olarak süresi içinde birden fazla kararname çıkarılıp çıkanlamayacă̆ hususunun yetki kanununda belirtilmesi yer almışur ${ }^{78}$.

Yetki kanununun, KHK'nin amacını, kapsamını, ilkelerini ve kullanma sürelerini somut bir biçimde belirtmesi gerekir. Bunlarda belirsizlik veya sürenin kabul edilemeyecek derecede uzun olması, yasama yetkisinin bir tür devri anlamına gelebileceğinden, hukuka ve Anayasa'ya aykırılık oluşur. Anayasa Mahkemesi 3347 sayılı kanunla 3268 sayılı kanunu değiştiren ve süresini uzatan ve bu kanunda değişiklik yapan 3479 sayılı yetki kanunu ile idari işlemlerin yeniden đüzenlenmesine dair 3481 sayılı yetki kanunlarını, kapsamının çok geniş olması, genel bir düzenlemeyi amaçlayan konuların somut oarak belirtilmemiş olması, KHK'ler için uyulması gereken "önemli, zorunlu ve ivedi durumlara özgülenmemesi ve verilen yetkinin uzun süreli olması" gerekçcleri ile iptal etmiş, 3911 sayılı yetki kanununun iptalinde de aynı gerekçelere dolayısıyla yer vermiştir ${ }^{79}$.

1982 Anayasası'nın 87. maddesi hükmünden KHK çıkarma yetkisinin belli konùlarda verileceği anlaşılmaktadır. Bu hüküm karşısında TBMM Bakanlar Kurulu'na ancak somut konularda KHK çıkarma yetkisi verebileccktir ${ }^{80}$. Bu belli konular sayılmamışır. Ancak sınırın belirlenmesi için başvurulacak bir dayanakur.

${ }^{78}$ Sağlam, a.g.e., s. $263,264$.

${ }^{79}$ Dp. 74 'deki karar.

${ }^{80}$ Anayasa Mahkemesi'nin 16.07.1991 tarihli ve e. 90/1, k. 91/1 (Siyasî Parti kapatma) sayıl kararı, Bilgen, a.g.e., s. 216 'dan naklen. 
1982 Anayasası'nın 91/1. maddesinde sayılan KHK ile düzenlenemeyecek konular ile 163. maddesinde belirtilen bütçede KHK ile değişiklik yapılamayacağına dair kural, belli konuları somutlaştırmaya birer ornektirler.

Yalnız içerik itibáryyla, Bakanlar Kurulu'na parlamento kararları alanına giren konular KHK ile düzenleyebilmesi için yetki verilmelidir. Çünkü daha önce söylendił̧i gibi parlamento kararları, organlar arası ilişkilere ilişkin ơzellik arzettikleri için kanun ठzzelliği taşımazlar. Diğer taraftan KHK ile bu çeşit düzenlemeler, kuvvetler ayrılığı prensibine aykırı olur ve yasamanın iç işlerine karışmak sonucunu doğurabilir.

\section{B- Yetki Kanununun Yürürlükten Kalkmasının KHK'ye Etkisi}

Yetki kanununun süresinin sona ermesi ya da çeşitli sebeplerle yürürlükten kalkması hallerinde ${ }^{81}$ yetki kanunu yürürlükte iken çıarılan ve henüz kanunlaşmayan KHK'lerin yürürlükte kalıp kalmayacakları konusunda farklı görüşler ileri sürülebilir.

Bunlardan birinci görüşe göre KHK'nin uygulanmasına devam olunur. Bu durum KHK'nin geçerliliğine engel olmaz. Çünkü KHK verilen yetkiye dayanılarak çıkarılmıştır. Yasama organı da böyle bir KHK'nin çıkarılabilmesini onceden kabul etmiş ve kendisine gelen KHK'yi yetki kanunun yürürlüğü sırasında incelememiştir. Bu tür incelemeyi yapıp yapmama veya bunu istediği zaman yapma takdiri ve sorumluluğu yasama organınındır. Üstelik yasama organı dileseydi. KHK'yi yetki kanunu yürürlükten kalkmadan inceleyebilirdi. Demek ki, burada, KHK üzerinde yasama organının iradesini bildirmesine kadar geçen zaman içinde kapalı bir kabulleniş vardır 82 .

Bunun karşısındaki ikincitez ise şu gerekçelere dayandırılabilir. KHK'nin geçerliliğini sağlayan yetki kanunudur. Yecki kanunun olmadan yürütme tarafından kullanılan bir tasarruf olmaz. Yetki kanununun yürürlükten kalkmasına rağmen bu kanuna dayanarak çıkarılan, fakat henüz kanunlaşmamıs KHK'yi uygulayan yürütme, kendiliğinden karar alan ve uygulayan organ haline gelecektir. Yetki kanununa dayanılarak çıkarılan KHK'nin yasama organına sunulması, TBMM genel kurulunda gorüşülmeden kanunlaştığı ya da kapalı bir şekilde kanun olarak kabul edildiği manasına gelmez. Bu durumda KHK ile yetki kanunu arasındaki bağın da koptuğu söylenemez; aksine KHK'yi yaşatan yetki kanunudur 83 .

Anayasa Mahkemesi'nin kararlarında ${ }^{84}$ bu görüşün benimsendiği görülmektedir. Yüksek mahkemeye göre, yetki kanunu ve KHK'nin birbirini tamamlayan işlemler olduğunu, KHK ile yeuki kanunu arasındaki bağın KHK'nin kanunlaşmasına kadar devam ettiğini, KHK'nin yasa gücünü dayanılan yetki kanununa uygun konulan esaslara uygunluğu ve yetki kanununun da Anayasa'ya uygunluğu varsayıldı̆ından dolayı kazandığını, yetki yasasının Anayasa'ya aykırılığının saptanması ya da bu nedenle iptal

81 Yürürlükten kalkma değiştirme, geri alma gibi şekillerde olabilir. Ömeğin Anayasa 91. maddesinde, KHK'nin onayı sıasında verilen yetkinin devam edip etmeyeceğinin belirlenmesi gerektiğini vurgulamaktadır.

.82 Fransız Danıştayı́nın da aynı görüşu benimsediği konusunda bkz. Kuzu, Türk..., s. 377.

${ }^{83}$ Kuzu, Türk..., s. $376,377$.

840meğin, bkz. dp. 40’da değinilen karar. 
karan verilmesi durumunda bu varsayım gerçekleşmediğinden, yetki kanununa dayanılarak çıkanılan KHK'nin yasal dayanaktan yoksun kalacağını ve bu durumda Anayasa'ya aykını hale geleceğini belirtmiştir.

Kanaatimizce, yürürlükten kalkan yetki kanununa dayanılarak çıkarılan ve henüz kanunlaşmamıs KHK'nin yukandaki gerekçelerle yürürlükten kalkması gerekir. Yalnız, bu gerekçelere bir husus daha eklenmelidir.

Yetki kanunu, yasama organınca, yürütme organı tarafından yürütülmesi için çıkarılır. Yetki kanununun yürütülmesi için de KHK çıkarılır. Şu halde KHK, kanunlmaşmadığı sürece, bir bakıma yetki kanunun yürütülmesinde özel nitelikli düzenleyici işlem niteliğindedir. Yetki kanununa somut bir şekilde bu anlamda KHK açısından bağlılık vardır. Şu halde, yetki kanununun kalkması ile, Bakanlar Kurulu'na bu kanunun yürütülmesi ile ilgili olarak verilen görev ve yetki de sona erer. Bu durumda Bakanlar Kurulu'nun özel nitelikli düzenleyici işlemi olarak KHK'nin de yürütülmesi mümkün olmaz ve dolayısı ile yürürlükten kalkar. verecektir.

Aslında KHK'nin kullanılma sürelerinin belirlenmesi, bu tür tartşmalara da son

KHK'lerin yetki kanununun kalkması nedeni ile Anayasa'ya aykın duruma düşmeleri dolayısı ile doğrudan yürürlükten kalkacakları sobylenebilir. Ancak, 1982 Anayasa'sına göre kanunlar ve TBMM i̧̧ Tüzükleri gibi, KHK'lerin Anayasa'ya aykınıklarını belirlemeye yetkili organ Anayasa Mahkemesi'dir (m. $148 \mathrm{vd}$ ).

Yetki kanunlarının kalkması sebebiyle hukuka aykın olduklarından dolayı kalkan KHK'nin yürürlükten kaldırılması işleminin geçmişe etkili olup olmayacağı konusu da ayn bir değerlendirme gerektirmektedir.

Bir kere, ttalyan Anayasası'nın -daha önce de değinilen- 77. maddesine göre, KHK'nin geçmişi etkileyecek şekilde yani yayımından itibaren kalkması, bundan doğabilecek hukuksal ilişskilerin de yasalarla düzenlenebilmesi ơngörülmüştür.

Yetki kanununun yürürlükten kalkması ile KHK'nin geçmişe etkili olarak yürürlükten kalkması konusunda belki şu gerekçeler ileri sürülebilir. Yetki kanunu kalkınca buna bağlı olan KHK boşlukta ve askıda kalacaktır. Dolayısı ile KHK, yapıldığı andan itibaren sıradan bir kararnameye yani düzenleyici işleme dönüşecektir. $O$ halde çıkuğı andan itibaren kanun kuvvetini kaybedecektir.

Fakat şurasını kabul etmek gerekir ki, KHK'nin yürütülmesi ile ortaya çıkan hukuki durumlar, topluma ve kişilere verilen güvenceler ve kazanılmıs haklar devlet tarafından kaldırılamaz. Kişilere ve topluma verilen bu tür güvenceler aynı zamanda devlet olmanın bir gereğidir. Aksine bir uygulama ile, KHK'leri yürürlüğe girdikleri tarihten itibaren geçersiz kabul etmek, kişi güvenliği ve hürriyetine aykınlık oluşturur.

1982 Anayasası 91 . maddesinde, KHK'lerin onaylanarak veya değiştirilerek ya da reddedilmek sureti ile kanunlaşacaklarını ve TBMM'nin buna dair bir kararının Resmi gazetede yayımlandığı gün yürürlüğe gireceği belirtilmiş olup, bundan, bir bakıma 
KHK'nin yürürlükten kalktığı günden itibaren hüküm ifade edeceği ve geçmişe etkili olmayacağı sonucu çıkmaktadır 85 .

\section{III- KHK'NIN UNSURLARI VE DIG̈ER BAZI YÖNLERI BAKIMINDAN ANALIZI}

\section{A- Unsurları}

\section{1- Amaç-Maksat}

Maksat ve amaç sözcükleri çoğunlukla aynı anlamda kullanılmaktadır. Konumuzla ilgili amaç, çıkarılacak KHK ile ulaşılmak istenen en son sonuç yanı kamu yararıdır. Amaç Bakanlar kuruluna KHK çıkarma yeıkiisinin neden verildiği ${ }^{86}$ yani yetkinin veriliş sebebini ifade cder.

KHK'nin amacı yetki kanununda gösterilir. KHK belirlenen bu amaçlara uygun olmalıdır ${ }^{87}$. Belirlenen amaç dışına çıkmak mümkün değildir ve bu anlamda taktir yetkisinden de bahsedilemez. Ancak, yetki kanununda birden fazla amacın yazılı olması halinde, KHK'de bu amaçlardan birisi seçilebilir.

\section{B- Sebep ve Konu}

Sebep, yönetimin işlem yapmasını gerektiren hukuki olaylar ya da işlemlerdir ${ }^{88}$.

Bu tanıma göre KHK yetki kanununda belirlenen amaç, ilke ve kapsam doğrultusunda çeşitli sebep ve gerekçelerle ihtiyaç duyulması halinde çıkarılabilir. Bu gerekçelere göre ihtiyacın olup olmadığını saptama ve bu ihtiyaçlar doğrultusunda KHK çıkanp çıkarmama taktiri Bakanlar Kurulu'nundur.

Örneğin; memurlanıın durumlarının iyileştirilebilmesi amacıyla KHK çıkarma yetkisi veren kanuna göre yükselen hayat pahalılığı gerekçe gösterilerek memur maaşlarının KHK ile artırılması durumunda neden hayat pahahlığı olmaktadır. Ya da yine aynı amaçla verilen yetkiye dayanarak, bir örgütte yapılan yükselıme işlemlerinden sonra üst kademelerde meydana gelen tıkanıklığın giderilmesi için KHK ile yapılacak yeni düzenlemenin nedeni ise, yükselmelerden meydana gelen tıkanıklıktır. Neden; birinci örnekte olaydan, ikinci ömekte ise hukuksal işlemden kaynaklanmaktadır.

KHK'lerin çıkarılması için gerekli "ivedilik ve zorunluluk" şartları, KHK'nin sebebi içinde düşünülen ve bu yönden diğer nedenlerle katkı özelliği taşıyan taktörlerdir.

Konu, yapılan işlemle ulaşlacak hedeftir ve sonuçtur. Bu bakımdan KHK'ler gözettiği hedef bakımindan yetki kanununda belirtilen amaçlarla uyumlu olmalıdır.

85 Ozbudun, $1961 \ldots$, s. 235.

86 Kuzu, Türk..., s. 327.

${ }^{87}$ Kuzu, Türk..., s. 327.

88 Yildizhan Yayla, Idare Hukuku, Istanbul 1985, s. 92. 
Ayrıca, KHK'nin yapılı̧ sebebi ile yapıldıktan sonra ulaşılan sonuç arasında bir nedensellik bağı bulunmaladır.

1982 Anayasası, 91/1. maddesinde sıkıyönetim ve olaganüstï haller saklı kalmak ùzere, Anayasa'nın ikinci kısmının birinci bölümünde yer alan temel haklarla kişi hakları ve ödevleri ile dördüncü bollümde yer alan siyasal hak ve ödevlerin KHK ile düzenlenemeyeceğini belirtmiştir. Ayrıca ana Anayasa'nın 163. maddesi, KHK ile bütçede değişiklik yapılamayacağını belirtmiştir. Kanaatimizce Bütçe ile ilgili diğer hükümler de KHK ile düzenlenemez. Cünkủ, değiştirme KHK ile yapılamayacak bir konunun baştan KHK ile düzenlenmesi de düşünülemez ve aynıca bütçenin yapılması ve kabulü için Anayasa ozzel hükümler öngörmüştür (m. 161 vd.). Bundan bütçenin kanunla düzenlenmesi gereği ortaya çıkmaktadır.

Bu durumda, vergi koymak, suç ve cezaların kanunla belirlenmesi gibi hususlar $^{89}$, Anayasa'mıza göre KHK ile düzenlenemeyecektir.

Anayasa'da KHK ile düzenlenemeyeceği belirtilen konular dışında kalan ve kanunla düzenlenmesi öngörülen konularda KHK çıkarılıp çıkarılamayacağı hususunda da farkh görüşler ileri sürülebilir.

Anayasa Mahkemesi'nin kararlanı ile ortaya çıkan ${ }^{90}$ birinci görüşe göre, Anayasa'nın 91. maddesinde KHK ile düzenlenemeyecek konular açıkça belirtilmiştir. Buna göre, yasaklanan bu istisnaya gimeyen ve kanunla düzenlenmesi öngörülen her düzenleme KHK ile yapılabilecektir. Kaldı ki, KHK de kanun kuvvetindedir.

Anayasa'da bazı konuların kanunla düzenlenmesi öngörülmekle birlikte, bu konuda "ancak kanunla düzenlenebilir" şeklinde açık bir sınırlama bulunmaması, bu konuları KHK ile düzenlenebileceğine dair ek gerekçe olarak belirtilebilir.

Anayasa kurallan tüm kurum ve kuruluşlan, özel ve tüzel kişilerle devletin tüm organlanı ıağlayan üst hukuk kurallandır. Bu bakımdan anayasa kurallan aynı zamanda bir talimat ve dircktif özelliği taşır. Kanunla düzenlenmesini istediği konular, bu yönü ile bir direktiftir. Üstelik aksi ifadenin bulunmamasından bu konuların KHK ile düzenlenebileceğini đüşünmek gerekir. Çünkü, KHK çıkarma yetkisini, aski Anayasa'da yazılı olmadığı gerekçesi ile kanunla düzenlemesi yapılacak konulara da yansıtmak mümkün değildir. Eğer bunun mümkün olduğu kabul edilecekse, buna kıyasla, örneğin; KHK'yi yapma yetkisinin de Bakanlar Kurulu dışında bir organa verilebileceği gibi garip ve kabul edilemez bir sonucun kabullenilmesi gereği ortaya çıkar. Çünkü, 1982 Anayasası Bakanlar Kurulu'na KHK çıkarma yetkisi verilebileceğini öngörmüş; ancak Bakanlar Kurulu dışında bir organın bu yetkiyi kullanamayacă̆ını belirtmemiştir. niteliktedir.

KHK'lcrin istisnai, ivedi ve zorunlu hallerde düzenlemesi gereği de bunu doğrular

${ }^{89}$ Kuzu, Türk..., 353 vd. Yazar kaide kararnamelerle adeta suç koymaktansa, kaide karamamelerle düzenlenebilecek bu konuların KHK ile düzenlenmesinin yeğlenmesi gerektiğini bildirmektedir, s. 357, 358.

90 Anayasa Mahkemesinin 08.02 .1989 tarihli ve e. $88 / 38$, k. $89 / 17$ sayll karan, Bilgen, a.g.e., s. 217 'den naklen. 
Bu konuda Anayasa koyucuya, bu tartışmaya son verecek bir şekilde yeniden düzenleme yapmak görevi düş̧ự̆ü söylense sanırzz yanlış bir ifade kullanılmış olmaz.

Kanunla düzenlenmesi gereken konular kimi zaman temel hakların bir uzantsi ơzellił̧ini taşıyabilir. Ömeğin memurun kamu hizmetlerinde yükselmesi eşillik ilkesi ile yapılacağına yaplacaktur ve eşitlik ilkesi de KHK ile düzenlenemeyecek.

Kanunla düzenlenmesi gereken konular kimi zaman temel haklarla ilgili olabilirler. Ömeģin memurların demę̧ vermelerine ilişkin bir düzenlemenin düşünce kanaati açıklama hürriyetini ilgilendirmesi gibi. Işte KHK ile yapılabilecek bu gibi durumlarda, temel hakların (ve bilhassa KHK ile düzenlenemeyecek olanlarının) sinurlanna dikkat edilmelidir.

KHK, tüzük gibi düzenleyici işlemlerle düzenlenebilecek konuları,düzenleyebilir. $\mathrm{Bu}$ durumda, bu tür konular, KHK konusunu oluştururlar ${ }^{91}$. Daha önce de söylendiği gibi bu konuların yetki kanununa uygun olması ve genel ve soyut nitclikler taşımaları gerekir.

\section{Yetki}

KHK çłkarma yetkisi Anayasa'ya göre Bakanlar Kurulu'na verilmiştir. Olağan dőnemlerde, bu yetki başka bir kişi, kuruluş veya organ tarafından kullanılamaz.

Bakanlar Kurulu tarafından çıkarılacak KHK, diğer kararnameler gibi Cumhurbaşkanı tarafından imzalanıp Resmi gazetede yayımlandıktan sonra yürürlüğe girecektir.

1982 Anayasası, KHK'nin Bakanlar Kurulu tarafından çıkarılabileceğini belirtmekle birlikte, 104. maddesinde Cumhurbaşkanı'na istedił̌i zaman Bakanlar Kurulu'na başkanlık etmek ve karamameleri imzalamak yetkisi verilmiştir. Bu nedenlerle KHK'nin de Cumhurbaşkaninca imzalanması gereklidir?2.

Parlamenter rejimlerde yürütme bilindiği gibi iki kanatı olup, sorumlu kanadı Bakanlar Kurulu, sonumsuz kanadı da Cumhurbaşkanı teşkil etmektedir ${ }^{93}$. Bu sebeple Cumhurbaşkanı'nın imzasının, şeklin tamamlanmasından ibaret olması gerektiği, belirtilmektedir ${ }^{94}$.

Konuya anayasal açıdan bakıldığında Cumhurbaşkanı'nın yukarıdaki hükümlerinden görüleceği üzere, KHK'yi imzalama ya da imzalamama yetkisi vardır; Cumhurbaşkanı tarafından imzalanamayan KHK'ler geçerlilik kazanamazlar.

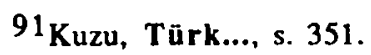

92 Ozbudun, Türk..., s. 202.

${ }^{93}$ Gözübüyük, a.g.e., s. 26; Tan, a.g.e., s. 42 .

94 Burhan Kuzu, Parlamenter Rejimde Devlet Başkanının Konumu ve 19611982 Anayasalarinda Durum, Istanbul, 1989, s. 11 vd; Soysal, a.g.e., s. 328, 329; Tan, a.g.e., s. 42; Ózbudun, a.g.e., s. 281 vd. 
KHK çıkarma yetkisi, süresi içinde kullanılır. Süresi içinde çıkarılmı̧ KHK'nin yasama organının tastikinden (iradesini belirtmesinden) önce, yayımlandığı gün TBMM'ne sunulmak kaydıyla, geri alınması, değiştirilmesi veya yürürlükten kaldırılması konusunda bazı görüşler ileri sürülebilir.

Birinci seçenek olarak KHK'nin TBMM'ne sunulduğ u andan itibaren Bakanlar Kurulu'yla arasındaki bağın kesildiği, bu andan itibaren bunun geleceğinin TBMM'nce belirleneceği, dolayısıyla artık geri alma ya da değiştirme gibi işlemlerin yapılamayacağını, TBMM'nin KHK üzerinde iradesi belli olmadan, aynı konuyu değiştirerek yeniden düzenleyemeyeceği, bunun aksine benimsenecek bir görüşün, KHK'lerin yayımlandıkları gün TBMM'ne bildirilmelerini anlamsız kılacağını ileri sürmek ${ }^{95}$ mümkündür.

Ikinci seçenek olarak, KHK'lerin TBMM'ne sunulmaları, bunlar üzerinde TBMM iradesinin aynı anda oluştuğu anlamına gelmez. Bu irade genel kurulda görüşülme sonucunda verilen kararla ortaya çıkar. Aradaki zaman içinde KHK'nin, çıkarmaya yetkili organ tarafından geri alınması, değiştirilmesi veya yürürlükten kaldırılması yetki ve usul paralelliğinin gereģidir. Usul Paralelliği yönetimin uyması gereken usuller ve yöntemler içinde yer alan, bir iş̧lemin yapılmasındaki esasa uyularak, deģiştirilmesi, kaldırılması veya geri alınmasını gerektiren bir ilkedir 96 .

Kanaatimizce, yetki kanunu geçerli iken yapılan KHK'nin değiştirilmesi, yürürlükten kaldırılması ya da geri alınması gibi yetkilcrin olup olmadığını değcrlendirebilmek için 1982 Anayasası'nın 91/2. maddesinin son cümlesine göre, Bakanlar Kurulu'na süresi içinde birden fazla karamame çıkarıp çıkaramayacağı konusunda yetki kanununda yer alan kurala göre hareket etmek gercklidir. Boyle bir durumda Bakanlar Kurulu'na birden fazla KHK çıkarma yetkisinin yetki kanunuyla verilmiş olması halinde, usul paralelliğine göre çıkarılan KHK'lerin, kanunlaşmadan önce, geri alınabilmeleri veya kaldınlabilmeleri mümkündür ${ }^{97}$.

Anayasa Mahkemesi çeşitli kararlannda KHK'nin Bakanlar Kurulu'nun TBMM'ye sunduğu KHK'leri değiştirebileceğini belirtmiştir 98 .

Yalnız, geri alma, kaldırma ya da değiştirme işlemlerinin sıradan bir kararname ile alınması yerinde değildir. Bu işlemler yine KHK'lerle yapılmalıdır ${ }^{99}$.

${ }^{95}$ Cahit Tutum, Şeref Gözübüyük, "Yasa Gücünde Kararnameler", Amme Idaresí Dergisi, c. V, sy. 1, s. 4 vd.

${ }^{96}$ Ali Ulku Azrak, "Betrachtungen Öber Form Und Verfahren In Der Türkischen Verwaltung" Istanbul Universitesi Mukayescli Hukuk Enstitüünün Travaux de la 5ème Semaine Juridique Turco Suisse'den Ayrı Basım, Istanbul 1976, s. 489.

97 Ozbudun, 1961..., s. 234; Ayrıca bkz. TBMM Iç̧üzügüü, değişik m. 90.

98 Yuksek Mahkeme'nin 08.10.1074 tarihli ve e. 1974/18, k. 42 sayılı kararı, Ozbudun, $1961 \ldots$ s. 235 , dp. 12.

${ }^{99}$ Kuzu, Türk..., s. 347 . Ayrica bkz. TBMM Iç Tüzügüü, md. 90. 
Uygulamada, Bakanlar Kurulu 1972 tarihli ve 1589 sayılı Yetki Kanunu'na dayanarak çıkarıldı̆̆ı KHK'yi, sıradan bir kararname ile, bu KHK Bütçe Komisyonu'nda reddedildikten sonra geri çekilmiştir ${ }^{100}$.

KHK'nin TBMM'nde kanunlaşmasından sonra, yetki kanunu halen geçerli olsa, değiştirmek, geri almak gibi şekillerde yeniden düzenlemenin mümkün olmadığını belirtmektedi, değiştirmek, geri almak gibi şekillerde yeniden düzenlemenin mümkün olmadığını belirtmektedirler ${ }^{101}$.

Buna göre, TBMM görüştügü KHK'yi kanunlaştırmıs ve bu KHK üzerinde ơzel olarak iradesini belirtmiştir. Şu halde bunların kanunlaşmalanndan sonra yeniden düzenlenmeleri mümkün değildir.

1982 Anayasası, bu konuda açık bir hükme sahip olmamakla birlikte, KHK'lerin TBMM tarafından onaylanması sırasında yetkinin son bulup bulmadığının belirtilmesini ơngörmüştür (m. 91). Onay, yapılan işlemin aynen kabul edilmesi demektir.

Diğer taraftan TBMM, verdiği KHK çıkarma yetkisi veya KHK üzerinde istediğii gibi bir tasarrufta bulunabilir.

- Bu bilgiler çerçevesinde, TBMM, gerek yetki kanunu ve gerekse KHK üzerinde istediği gibi tasarrufta bulunabilme yetkisine sahip olmasına karşılık bunlār üzcrinde iradesini belirtirken istisna getirmediği ve yetki kanununun' geçerliliği kabul olunduğu sürece, KHK, kanunlaşmış haliyle yetki kanunu kapsamında yeralmak kaydıyla, KHK deģiştiren, kaldıran ya da onaylayan kanunun yeniden KHK ile öyle ya da böyle düzenlenmesinde hukuksal bir engelin olmadığı söylenebilir ${ }^{102}$.

Bakanlar Kurulu'na verilen KHK çıkarma yetkisi, Bakanlar Kurulu'nun istifası veya đüşmesi ya da yasama döneminin sona crmesi sebepleri ile sona ermez (m. 91). 1961 Anayasası döneminde bu konuda ciddi tartışmalann ortaya çıktığını gören Anayasa Koyucu, 1982 Anayasası'na koyduğu bu hüküm ile bu tartışmaları sona erdirmiştir.

Daha ơnce de değinildiği gibi, 1961 Anayasası'nda yer alan, çıkarılācak KHK'de yetkinin dayanağı ve kaldırılan kanun hükümlerinin belirtilmesi gerekleri 1982 Anayasası'na konmamıs yetki ile ilgili diğer kurallardır.

Fakat, birden fazla yetki kanununun bulunması hallerinde çıkarılan KHK'nin dayanağının belirtilmesi bir bakıma zorunluluk arzeder. Bunun gibi, KHK'nin kaldırdığı kanun hükümlerini belirtmesi de çok yerinde olurdu.

\section{D- Usul ve Şekil}

KHK'nin yapılması sırasında uyulması öngörülen özel bir usul hükmü yoktur. Bakanlar Kurulu KHK'leri, tıpkı diğer kararnameler giobbi, kararlaşırarak çıkarmaktadır.

100 Duran, a.g.e., s. 17; Kuzu, Türk..., s. 348.

101 Kuzu, Türk..., s. 348.

${ }^{102}$ Bazı Fransız yazarların da aynı görüşte olduklan belirtilmektedir. Bkz. Kuzu, Türk... s. 348 . 
Yapılması ve çıkarılması bakımından KHK'lerin diğer kararnamelere benzediği sőylencbilir.

KHK'ler de diğer kararnameler gibi Bakanlar Kurulu'nda oybirliği ile çıkar. Çünkü Bakanlar Kurulu'nda kararlar hep oybirliği ile alınır; oy çokluğu ile alınan kararlar geçerli değildir ${ }^{103}$. Çünkü Bakanlar Kurulu'nun sorumluluğu birlikte sorumluluktur. Uygulamada kararların bakanlara elden imzalaularak kararnamelerin yapıldığı ve Bakanlar Kurulu'nun çalışmasını düzenleyen iç tüzük kurallarına ihtiyaç olduğu belirtilmektedir ${ }^{104}$.

1982 Anayasası'nın 91. maddesine göre;

"KHK'ler, Resmi Gazetede yayımlandıklan gün yürürlüğc girerler. Ancak, kararnamede yürürlük tarihi olarak daha sonraki bir tarih de gösterilebilir.

Kararnameler Resmi Gazete'de yayımlandıkları gün TBMMne sunulurlar.

Yetki kanunlari ve bunlara dayanan KHK'ler, TBMM komisyonları ve genel kurulunda öncelikle ve ivedilikle görüşülür.

Yayımlandıkları gün TBMM'ne sunulmayan kararnameler bu tarithe, TBMM'nce reddedilen kararnameler bu kararın Resmi Gazetede yayımlandığı tarihte, yürürlükten kalkar. Değiştirilerek kabul edilen kararnamelerin değiştirilmiş hükümleri, bu değişikliklerin Resmi Gazetede yayımlandığı gün yürürlüğe girer."

KHK'lerin yürürlüge girebilmesi için gerckli olan Resmi Gazete'de yayımlanma ve bu yayımın yapıldığı gün TBMM'ne sunulma şartlannda birisinin gerçekleşmemesi halinde KHK geçerlilik kazanamaz. Yayımlanma veya TBMM'ye sunulmada gecikmenin haklı scbebe dayandığı iddiası yerinde görülemez. Gecikme halinde KHK'nin yürürlük tarihi, KHK'nin işlemlerinin Anayasa hükmü çcrçevesinde tamamlandığg tarihtir ${ }^{105}$.

Ayrıca yetki kanunları ve KHK'lerin öncelikle ve ivedilikle görüşülmeleri, TBMM'nin bunlara çalışmalarında öncelik vermesi ve bunlan hızla görüşmesi demcktir.

Nitckim TBMM Iç Tüzü̈̆̈̈̈, KHK'nin kanun tasan ve tekliflerinden önce ve ivedi görüşüleceğini (m. 90); esas komisyonlarda 45 (tali komisyonlarda en fazla 10) gün bekleyeceğini; süresi içinde görüşülmeyen KHK'nin doğrudan Genel Kurul gündemine alınmak üzere Meclis Başkanlığı'nca Danışma kuruluna götürüleceğini, KHK'nin süresi bitiminde Genel Kurul gündemine alınmasını hükümetin isteyebileceğini belirtmektedir (m. 37).

${ }^{103}$ Gözübüyük, Yönetím..., s. 55 .

${ }^{104}$ Gözübüyük, Yönetim..., s. 55 .

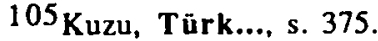


Birden fazla KHK'nin bulunması halinde hangisinin öncelikle görüşüleceği konusunda üç seçenek ileri sürmek mümkündür ${ }^{106}$. tlk sıradaki KHK'den başlamak ve surasıyla gitmek, sondan başa doğn gelmek ya da istenilen yerden başlayıp devam etmesi. Uygulamada TBMM'nin istediǧinden başladığı görülmektedir. Anayasa Mahkemesi'ne göre onemli olan bu tür KHK'lerin gündemdeki diğer kanun tasarı ve tekliflerinden öncelikle ve ivedilikle görüşülüp karara bağlanmasıdır... kararnamelerden birinin ठttekilerden daha önce gơrüşülmesi anayasa sorunu olmaktan çıkmış ve yasama meclisleri komisyonlarının genel görüşme usulleri içinde gơrüşülhmesi gereken bir duruma düşmüştür" 107.

1982 Anayasası'nın ifadesinden, TBMMnnin KHK'ler üzerindeki iradesini "karar" seklinde ortaya koyacağı anlaşılmaktaysa da, TBMM'nin KHK üzerindeki iradesinin hukuksal tanımı, niteliği kanundur. TBMM'nin KHK'yi değiştirmesi ya da onaması veya reddetmesi ile ilgili olarak Anayasa'nın 91. maddesinde geçen "karar" deyimi, teknik anlamda bir parlamento kararı olamaz; olsa olsa, işin sonuçlandırılması anlamında kullanılan bir ifade olabilir ${ }^{108}$. Gerçekten, tüm devleti, ve muhataplarını ilgilendiren, hak ve yükümlülükler oluşturan bu tür iradeler karar adıyla da anılsa, zaten kanun ozelliğindedir. Kaldı ki uygulamada TBMM'nin KHK üzerindeki hukuksal iradesi kanun olarak ortaya çıkmaktadır.

KHK'nin onaylanması veya reddi, ilgili KHK'ye yollamada bulunan ve sırf bu iradeleri yazan bir kanunla yapılabilir. Ancak, KHK'nin değiştirilerek kabulü halinde, en azından değişik ifadeler zorunlu olarak yasaya işlenir.

KHK'lerin reddine ya da değiştirilerek kabulüne dair kanun Resmi Gazete'de yayımlandığı gün yürürlüğe girer. Yasa koyucu aynca bir yürürlük tarihi saptayamaz. Bu durum, KHK'lerin reddedilen kısımlarının, yürürlükten kalkarken geçmişe etkili olamayacaklarını göstermektedir. KHK'lerle oluşan hukuki durumlar ve kazanılmış haklar böylece korunmuş olur ${ }^{109}$.

Anayasa'nın bu açık hükmüne rağmen ${ }^{110} 15.05 .1975$ tarihli ve 1896 sayılı kanunun, 11 sayılı KHK'yi bütün sonuçları ile ortadan kaldırması Anayasa'ya aykınılı taşımaktadır $^{111}$. Bu kanun, Anayasa Mahkemesi'nce henüz şekil incelemesinde ve esasa gelinmeden iptal olunmuştur.

KHK'lerin TBMM tarafından reddedilmesi halinde ortaya çıkacak boşluğun doldurulması konusunda, bazı yazarlar, eski kanunun yürürlüğg tekrar gireceğini, çünkü KHK ile kaldırılan kanun hükümlerinin bir çeşit "askıya alındığını"112 belirtmektedirler.

106 Ozbudun, Türk..., s. 203; Özbudun, 1961..., s. 234.

107 Anayasa Mahkemesi'nin 14.10.1975 tarihli ve e. $1975 / 45$, k. 1975/198 sayıl kararı, Ozbudun, 1961..., s. 234 'den naklen.

108 Ozbudun, 1961.... s. 235; TBMM Içtizliğu değişik m. 90/2.

109 Ozbudun, $1961 \ldots$ s. $236,237$.

$110_{1961}$ Anayasasının 64. maddesi.

111 Ozbudun, Türk..., s. 205.

112 Duran, Kanun..., s. 5. 
Kanaatimizce, KHK'nin reddine dair kanunda boşluğu giderecek başkaca bir hüküm yoksa, kaldırılan kanun hükmü tekrar doğrudan doğruya yürürlüğe giremez. Çünkü, KHK ile değiştirilen kanun hükümlerinin askıya alınmamışur. Eğer KHK ile değiştirilen kanun hükmü her hangi bir kişi ya da organ tarafından uyulması zorunlu kural olsaydı, bu durumda belki askıya alınma tezi kabul edilebilirdi. Bu durumda eşitlik ilkesine aykınlık oluşurdu. Kaldı ki yetki kanunu değiştirilebilecek kanun hükümlerini kapsamınđa belirtmiş ve bu yönde KHK ile yapılabilecek değişiklikleri kabullenmiş, redde dair kanunda da yeni bir kural koymamışsa, KHK ile yüriürlükten kalkan kanun hükmünün uygulanması uygun olamaz

Ortaya bu şekilde çıkan boşluk kural olarak TBMM tarafından yasama işlemi olan yasa ile giderilmelidir. Ancak, başta da söylendiği gibi, kanunla düzenlenmeyen bir konuda yơnetimin doğrudan Anayasa hükümlerini uygulayabileceği tezi daha akla yakın görünür gibidir. Ancak, kanun koyucunun böyle bir yol ile KHK'yi reddetmesi halinde, ortaya çıkacak boşluğu gidermesi gerekmektedir ${ }^{113}$.

\section{E- KHK'lerin Yargisal Denetimleri}

KHK kurumu 1961 Anayasası'na gorre 1971 tarihinde 1488 sayilı kanun ile eklenmiş, fakat bunların yargısal denetim rejimine ilişkin kurala aynı Anayasa'da yer verilmemiştir.

Şekli ve organik bakımdan yönetsel; maddi (fonksiyonel-işlevsel) açıdan ise kanunlar gibi kural işlem olmaları, KHK'lerin yargısal denetimlerinde farklı düşüncelerin ortaya atılmasına neden olmuştur.

Bazı yazarlar KHK'lerin yürütme işlemi olmaları gerekçesiyle Danıştay'ın denetimine tabi olduklarını ileri sürmüşlerdir ${ }^{114}$. Biraz daha farklı bir görüs ise, KHK'lerin kanunlaşmadan evveel Anayasa'ya ve hukukun diğer ilkelerine uygunluklan bakımından Anayasa Mahkemesi'nce; yetki kanununa ve kaldırılmalan yetki kanununda öngörülmemiş olan diğer kanunlara uygunlukları bakımından Danıştay tarafından denetlenebileceği düşüncesindedir ${ }^{115}$.

1961 Anayasası'nın yürürlük döneminde Danıştay, 2. sayllı KHK'nin iptali için kendisine dava açılan davayı, "davanın inceleme kabiliyeti bulunmadığı" gerekçesiyle reddetmiştir. Bu karar ise bir "Hükümet Tasarrufu" şeklinde yorumlanmıştır. Çünkü Danıştay KHK'yi inceleme yetkisinin başka yargı merciine -örneğin Anayasa Mahkemesi'ne- ait olduğunu belirtmek isteseydi, "görevsizlik karan" vermeliydi ${ }^{116}$.

Artik 1982 Anayasası, KHK'lerin yargısal denetiminin Anayasa Mahkemesi'ne ait olduğunu belirterek ( $m$. 148) bu alanda tartuşmalara son vermiştir.

113 Yönetimin kanun olmayan bir alanı Anayasa'yı uygulayarak düzenleyip düzenleyemeyeceği hususu daha evvel tartışılmıştı. Burada, Anayasa'nın aynı zamanda bir kanun olduğunu belirtmek tamamlayıcı nitelikte olacaktır.

114 Teziç, Yasama..., s. 12.

115 Duran, Idare..., s. 476.

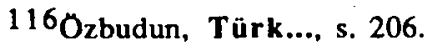


Bu bakımdan, KHK'lerin ayn bunlanı onaylayan veya değiştiren ya da reddeden kanunlanın ayn ayn işlemler olup olmadıklarının ${ }^{17}$ belirlenmesi de bir şey ifade etmez. Çünkü gerek KHK ve gerekse kanun aynı yargı denetimi rejimine tabidir.

Bu konuda yine de bir kanaat belirtmck gerekirse, bize göre, KHK'yi tamamen veya bir kısmını onaylayan kanun, KHK'den ayrı düşünülemez.

Daha ơnceki yerlerde kısaca değinildiği gibi KHK, yargı denetimi bakımından, Anayasa'ya ve yetki kanununa aykınlığı saptanıncaya kadar uygulanmalıdır. Yetki kanununun Anayasa'ya aykınlığı sebebiyle, Anayasa'ya aykınlığı saptanmayan KHK'nin hakkında da kanaatimizce iptal karan verilmelidir.

Yalnız, ortada bir yetki kanunu yokken olağan dönemlerde KHK çıkarmak kesinlikle mümkün olmadığından, kanaatimizçe bu durumdaki KHK'lerin, yargı kararı beklenmeden uygulanmasının doğrudan doğruya durdurulması gerekmektedir.

\section{IV- SONUÇ YERINE: KHK'LERIN HUKUKA UYGUNLUĞU IÇIN GEREKLI HUSUSLAR}

Bir kısmı buraya kadar verilen bilgilerin bir tür ozeti olmak ve sıkıyönetim ile olağan üstü haller saklı kalmak üzere, çıkarılacak KHK'lerin hukuka uygunluklan için şunlar söylenebilir.

1- KHK'lher yetki kanununa bağlı ve bu kanunda belirtilen unsurlara uygun olmalıdırlar. Aksi halde, çıkarılan KHK'ler Anayasa'ya aykırı duruma düşerler ${ }^{118}$.

Anayasa Mahkemesi 3268, 3347 ve 3479 sayılı Yetki Yasalarına dayanılarak yürürlüğc konulan 335 ve 347 sayılı KHK'leri, dayandınldıkları Yetki yasasının kapsamı dışında kalmaları nedeniyle iptal etmiştir ${ }^{119}$.

2- KHK'lerin hukuka uygunluklan için yetki yasasına dayandırılmazı yetmez. Ayrıca, ivedi ve zorunlu hallerde KHK çıkarma yoluna başvurulmahdır. Yoksa yetki kanununun KHK çıkarma konusunda mutlak yetki verdiği söylenemez.

3- Yukarıdaki husus ile bağlantılı olarak denilebilir ki KHK çıkarma yetkisi sürekli kullanılmamalıdır. KHK'lerin bu şckilde yaygınlaştınılması, zorunluluk ve ivedilik şartlarına uyulmadığının göstergesi olabileceği gibi, bu haliyle, yasama yetkisinin devredilmezliği prensibine de aykırı olabilir.

Bir yazar, KHK'ye başvurma yolunun yaygınlaştırılmasının, parlamentonun çalışmamasına sebep olabileceğini ve parlamentoyu, siyasi karäların alındığı ve tarışmaların yapıldığı merkez olmaktan uzaklaştırabileceğini belirtmektedir ${ }^{120}$.

117 Teziç, a.g.e., s. 11; Özbudun, $1961 \ldots$,.., s. 236.

118 Ozbudun, Türk..., s. 200.

119 A MKD., sy. 29, c. I, Ankara, 1994, s. 383.

${ }^{120}$ Sağlam, a.g.è., s. $270,271$. 
4- 1982 Anayasası'nın ikinci kısmının birinci ve ikinci bølümündeki temel haklarla kişi haklan ve ödevlerinin ve dördüncü bölümündeki siyasal ak ve ödevlerinin KHK'lere konu olmaması gerekir. Buna göre örneł̆in, Anayasa'nın 70 . maddesine göre siyasi haklar ve ödevler bölümünde yer alan kamu hizmetlerine girme hakk, KHK ile düzenlenmemelidir.

Bunların dışında kalan ve 1982 Anayasası'nın 41. (dahil) ile 65. (dahil) maddeleri arasında yer alan "Ekonomik ve Sosyal Haklar ve Ödevler" bir yasaklama olmadığı için, KHK'lerle düzenlenebilecektir ${ }^{121}$.

Sağlam'a göre düzenleme sınırlamayı da içerir ve sınırlamadan daha geniştir. Düzenlemeden temel hakların en uygun bir şekilde kullanımı anlaşılmalıdır. KHK'lerle düzenlenemeyeceği belirtilen konular dışında kalan ekonomik ve sosyal hak ve ödevlerin KHK'lerle düzenlenebilmesi sadece Anayasa'nın 65. maddesine göre devletin vatantaşlara karşı olan edimlerinin daha çabuk yerine getirilebilmesi amacına yönelik olmalıdır. Çünkü, Anayasa tem hakların kanunla sınırlanılabileceğini belirtmiştir ${ }^{122}$.

Hürriyetler bir bütündür ${ }^{123}$. Insan haklarının birisinin tanınıp diğerinin tanınmaması, o alanda insanın insan olmaktan dolayı getirdiği hakları kullanamaması demektir. Insan haklanı, insanın pasif veya aktif halde iken sahip olduğu tüm haklan ifade etmekte olup ${ }^{124}$, devlete karşı ileri sürülebileceḱk haklardır.

KHK'lerle düzenlenebilecek temel haklar için insana verilen değer gözardi edilmemeli ve mümkün olduğunca temel haklanı sınılayacak kurallar konmamalıdır.

Bunun gibi, KHK'lerle düzenlenebilecek ya da düzenlenemeyecek temel haklarla ve odevlerle ilgili olan konular da düzenlenebilmesi ya da düzenlenememesi bakımından kurallarına tabi olmalıdır. Daha açık bir ifade ile, KHK'lerle düzenlenemeyecek temel haklarla her hangi bir yönden ilgili olabilecek konularda da düzenleme yetkisi kullanılamayacaktrr. KHK'lerle düzenlencbilecek temei haklar ve odevlerle her hangi bir yőnü ile ilgili konularda ise düzenleme yetkisi kullanlabilecektir.

5- KHK'lerin yayımlandıklan gün TBMM'ne sunulmaları gerekmektedir. Yetki kanunları gibi bunlar da TBMM'nin komisyonlarında ve genel kurulunda öncelikle ve ivedilikle görüşülmelidirler. Uygulamada, birden fazla KHK'nin bulunması halinde TBMM (komisyonları ve genel kurulu) inceliği istediğinden başlatmaktadır.

Düşüncemize göre, görüşmelerde öncelik ve ivedilik sırasının bclirlenmesinde, varsa öncelik ve ivedilik bakımından diğer konular saklı kalmak üzere, sosyal ve ekonomik haklar ve ödevlerin düzenlendiği KHK'ler gözönünde tutulmalıdırlar.

${ }^{121}$ Tanilli, a.g.e., s. 411 vd.

122 Sağlam, a.g.e., s. 268, 269.

${ }^{123}$ T. Zafer Tunaya, Siyasal Kurumlar ve Anayasa Hukuku, Istanbul, 1982, s. 229; Münci Kapani, Kamu Hürriyetlerl, Ankara, 1981, s. 16.

${ }^{124}$ Richard F. Behrendt, Die Würde Des Menschen, Hannover, 1967, s. 11, 12. 
6- Tüm bunlardan başka, Bakanlar Kurulu'na KHK çıarabilmesi yetkisi veren yetki kanunu, çıkarılacak KHK'nin, amacını, kapsamını, ilkelerini, kullanma süresini ve süresi içinde birden fazla KHK çıkarılıp çıkarılamayacağını açık ve somut olarak belirlemilidir. Amaç, kapsam ve ilke bakımından yeterince belirli olmayan ve uzun sayılabilecek zaman için kullanma süresi öngören yetki, kanunlan, hukuka aykını olurlar; çünkü bu bir tür yasama yetkisinin devri niteliğini taşır.

Burada ơnemli saydığımızdan tekrar belirtmek isteriz ki, daha önce değindiğimiz gibi, kullanma süresinin yetki kanunu ya da KHK'lerden hangisi için ơngörüldügüü daha açık ve ikilemi giderecek şekilde belirlenmelidir. Yine yetki kanununda amaç, ilke ve kapsama, çıkarılacak KHK'de gözönünde tutulacak hususlar olarak yer verilmelidir.

Bir de Anayasa'da kanunla düzenlenmesi belirtilmiş konulann mümkün olduğunca KHK'lerle düzenlenmemesi gerekir. belirlenmelidir.

Bunların KHK'yle düzenlenebilecek olanları Anayasa koyucu tarafından

KISALTMALAR

$$
\begin{aligned}
& \mathrm{dp} . . . . \ldots \ldots . . . . \text { dipnot } \\
& \text { k.............karar sayısı } \\
& \text { e............esas sayısı }
\end{aligned}
$$

TBMM............. Türkiye Büyük Millet Meclisi

AMKD............. Anayasa Mahkemesi Kararlar Dergisi

AÜSBF.............Ankara Üniversitesi Siyasal Bilgiler Fakültesi

bkz.............bakınız

vd.............ve devami

sy..............sayı

s............. Sahife

c.............cilt

m............ madde

Aynca; dipnotlarda adlan verilen yazarların, tekrarında, yazarın soyadı ve sahife numaralan ile yetinilmiş; aynı yazarın farklı yayımlarının tekrarlarında ise yazarın soyadı ve yayımın adının ilk sözcügü yazılarak kısaltılmışır. 